NBER WORKING PAPER SERIES

\author{
FACULTY DEPLOYMENT IN RESEARCH UNIVERSITIES \\ Paul N. Courant \\ Sarah Turner \\ Working Paper 23025 \\ http://www.nber.org/papers/w23025
}

\author{
NATIONAL BUREAU OF ECONOMIC RESEARCH \\ 1050 Massachusetts Avenue \\ Cambridge, MA 02138 \\ January 2017
}

We would like to thank Austin Slaughter, Aaron Phipps, Fran Murphy and Emily Cook for their patience and their exemplary research assistance. We are also grateful for the efforts of George Stovall of the University of Virginia and Ben Koester of the University of Michigan in helping us to acquire and understand institutional data. We also received valuable comments from Kevin Stange and from Ron Ehrenberg. The views expressed herein are those of the authors and do not necessarily reflect the views of the National Bureau of Economic Research.

NBER working papers are circulated for discussion and comment purposes. They have not been peer-reviewed or been subject to the review by the NBER Board of Directors that accompanies official NBER publications.

(C) 2017 by Paul N. Courant and Sarah Turner. All rights reserved. Short sections of text, not to exceed two paragraphs, may be quoted without explicit permission provided that full credit, including $(\odot$ notice, is given to the source. 
Faculty Deployment in Research Universities

Paul N. Courant and Sarah Turner

NBER Working Paper No. 23025

January 2017

JEL No. I23

\begin{abstract}
$\underline{\text { ABSTRACT }}$
Deploying faculty efficiently (or more efficiently) should surely part of any optimizing strategy on the part of a college or university. Basic microeconomics about the "theory of the firm" provide some insight as to how a university would achieve productive efficiency given differences in the price (salary rate) of faculty across disciplines and variation in compensation within departments. The prices of faculty activities demonstrate substantial variation across institutions, disciplines, within disciplines and over time. These observations about variation in input prices raise fundamental questions about whether and, if so, how differences in the cost of faculty affect resource allocation at research universities. We examine how teaching allocations and costs vary both between departments and within departments. This allocation is complicated because teaching and research are jointly produced by universities, while they are also substitutes at some margin in faculty time allocation.
\end{abstract}

We examine the link between departmental compensation (payroll) and student course offerings at two major public research universities. Strikingly, we find that faculty compensation per student taught varies much less across departments than salary levels. In turn, changes over time in relative salaries by discipline are much larger than changes in faculty compensation per student as universities adjust to these cost pressures by increasing class size and increasing teaching inputs from other sources. We also find that within departments the highest-paid faculty teach fewer undergraduates and fewer undergraduate courses than their lower-paid colleagues. This finding confirms our hypothesis that salaries are determined principally by research output and associated reputation, and that universities respond rationally to relative prices in deploying faculty.

Paul N. Courant

Harold T. Shapiro Collegiate Professor of Public

Policy, Arthur F. Thurnau Professor,

Professor of Economics and of Information

Gerald R. Ford School of Public Policy

University of Michigan

4126 Weill Hall

Ann Arbor, MI 48109-3091

pnc@umich.edu

Sarah Turner

University of Virginia

Department of Economics

Monroe Hall, Room 237

248 McCormick Rd

Charlottesville, VA 22903

and NBER

sturner@virginia.edu 


\section{Faculty Deployment in Research Universities}

\section{Paul N. Courant (University of Michigan) and Sarah Turner (University of Virginia)}

It is sometimes asserted that higher education institutions are inefficient and wasteful. Perhaps they are. ${ }^{1}$ Whatever else is going on, however, faculty continue to be a major source of cost and account for more than 2/3 of instructional expenditures at public universities. Deploying faculty efficiently (or more efficiently) should surely be part of any optimizing strategy on the part of a college or university. The principal issue addressed in this paper is the extent to which faculty in research universities are deployed efficiently in the context of an environment in which their institutions are called upon to produce instruction and research.

Basic microeconomics about the theory of the firm provide some insight as to how a university would achieve productive efficiency in deploying faculty and other resources across departments and within departments given market wages by discipline. Still, the case of the allocation of faculty time to teaching responsibilities in academe is distinct for at least three reasons. First, moving resources between academic departments is cumbersome. One cannot generally redeploy faculty across fields of expertise. Increasing the size of the Philosophy department while reducing that of Chemistry generally cannot be accomplished by moving a chemist's research from her lab to the library and her teaching from inorganic chemistry to epistemology. Rather a decision to grow Philosophy and shrink Chemistry can only be fully implemented when a chemist (and it won't be just any chemist, depending on the configuration of expertise and the desirability of same within the department) retires or leaves the department

\footnotetext{
${ }^{1}$ Critics of rising tuition levels in higher education commonly refer to growth in administrative and support service as evidence of "bureaucratic bloat" (see, for example, Campos (2015)) while increased amenities that would appear to be unrelated to student learning are cited as examples of wasteful expenditures (see, for example, Jacob, McCall, and Stange (forthcoming) and popular press articles that followed).
} 
for other reasons. In effect, there is little (or no) short-run opportunity for substitution of faculty across disciplines, and the length of time required to make long-run adjustments can be long indeed. In contrast, within departments, faculty effort can be reallocated between teaching and research directly and indeed there is a good deal of variation in faculty teaching loads and research expectations. Tenure-track faculty are often employed in the production of multiple outputs, including research as well as teaching students of different levels. Finally, the "technology of learning" as well as physical space limitations of universities may limit the extent to which universities can change class sizes in response to the differential cost of faculty.

The salaries of faculty exhibit substantial variation across disciplines, within disciplines and over time. Yet, particularly in undergraduate education and doctorate education in the arts and sciences, universities rarely engage in differential pricing (Stange, 2015). Nevertheless, there are surely large differences in the cost of production for courses across departments and within departments at a university, and these differences derive in large part from differences in faculty salaries, class size and teaching loads. These observations raise fundamental questions about whether and how differences in the cost of faculty affect resource allocation at research universities. In an effort to understand the production function of the research university, we examine how teaching allocations and costs vary both between departments and within departments.

The allocation of faculty to different activities is complicated because teaching and research are jointly produced by universities, while they are also substitutes at some margin in faculty time allocation. It follows that the allocation of faculty time to teaching - determined by how many courses a faculty member teaches and how much effort is expended in the teaching may bear little relationship to how many students a faculty member enrolls and, in turn, how 
much tuition revenue is generated. Recognizing different research productivity among faculty and different market prices for research across disciplines suggests a model in which university and department level decision- making incorporates input prices to approach efficiency in the deployment of faculty to teaching and research.

The questions are brought into sharp focus by the fairly dramatic changes in faculty salaries across fields in recent decades at research universities. Overall, a rise in faculty salaries should be relatively unsurprising in an overall labor market where returns to education are increasing. At the same time, there has also been considerable heterogeneity across fields. Disciplines like economics have seen dramatic increases in faculty compensation, while salaries have increased only modestly in many fields in the humanities. Significantly, the salary increases seen at research universities are not shared across all sectors of higher education.

It is research universities (in the U.S., members of the Association of American Universities and, to a substantial degree, members of the larger Association of Public and Landgrant Universities), where the same personnel (tenure track faculty) do much of both teaching and research that are the focus of our analysis. These research-intensive public universities award a substantial share of graduate and undergraduate degrees, accounting for $36.5 \%$ of doctorate degrees and $16.7 \%$ of BA degrees awarded by US institutions in $2015 .{ }^{2}$ The university has two important margins as it allocates faculty resources. It can move resources between departments and schools, growing, say, computer science while shrinking, say, comparative literature, ${ }^{3}$ and it can also move resources between teaching and research within departments. To

\footnotetext{
${ }^{2}$ Authors' tabulations from the IPEDS survey, focusing on those classified as "Research I" under the Carnegie Classification.

${ }^{3}$ In some places these are in different colleges or schools within the university. We are ignoring that the complications created by professional schools, but supposing that there is some authority that can reallocate across broad lines of academic activity. For that matter, a university can grow the football team while shrinking the library, a margin that we will also ignore, sticking here to academic departments, and, for reasons that will become clear, a subset of academic departments.
} 
set the stage for our analysis of instructional production in the research university, we begin with a brief overview of the trends in the faculty labor market, where supply generated by doctorate programs and demand from universities and the non-academic market determine price. We focus our analysis on the public universities where data are generally available in the public domain. Section three sets forth the theoretical framework where we outline a model of how universities allocate faculty to teaching across and within departments. Section four investigates the link between departmental compensation (payroll) and students and courses taught, leading to measures of the distribution of class sizes and "cost per seat." A simple and important takeaway is that faculty compensation per student varies less across departments than salary levels. In turn, changes over time in relative salaries by discipline are much larger than changes in faculty compensation per student as universities adjust to these pricing pressures by increasing class size and increasing teaching inputs from other sources.

We find that within departments the highest-paid faculty teach fewer undergraduates and fewer undergraduate courses than their lower-paid colleagues. Following the logic of our theoretical discussion in Section three, this finding confirms our view that salaries are determined principally by research output and associated reputation, and that universities respond rationally to relative prices in deploying faculty.

Our finding that research universities respond rationally to differences in prices and opportunity costs of faculty deployment suggests, although it does not prove, that universities endeavor to be efficient in the classic economic sense of minimizing the cost of producing output. That university leadership recognizes and acts upon opportunities to increase productivity in the important domain of allocating faculty to teaching and research suggests that we are likely to find similar efforts in other domains. 
We end with a brief conclusion that summarizes our results and their implications, and suggests further work.

\section{Faculty Labor Markets: Trends and Compensation by Discipline}

\section{$\underline{\text { Faculty Salaries }}$}

Faculty salaries represent the price of the primary input in the higher education production function. The relative increase in the earnings of college-educated workers has been widely noted (see, for example, Autor, 2014) and one might think this premium is particularly concentrated among doctorate recipients, who are at the top of the distribution of years of educational attainment. Over the course of the last quarter century, faculty salaries have risen (Figure 1) and these increases are somewhat larger than the earnings changes for collegeeducated workers more generally. ${ }^{4}$ Since 1990 , constant dollar faculty salaries have increased by $14 \%$ at the level of full professors and by $10-11 \%$ for associate and assistant professors. For colleges and universities, an increase in the price of faculty, the most significant input in the university budget, affects costs of production. Yet, as discussed in more detail below, the rising tide has not lifted all boats and the increase in faculty salaries has been concentrated among universities in the research sector and faculty in a subset of academic disciplines.

Even as the faculty salary bill continues to dominate university expenditures on instruction as there has been little - if any - substitution of capital and technology for doctorate level instructors in the university production for, quite literally, centuries. What some have labeled the "cost disease" would seem to be a significant force in explaining the long trend of

\footnotetext{
${ }^{4}$ Data from the Current Population Survey P-20 series show an increases in the constant dollar earnings of workers with at least a BA degree between 1991 and 2014 of $3.4 \%$ for men and $11 \%$ for women.
} 
rising costs in higher education. ${ }^{5}$ Over the last two decades, there have been few changes in staffing ratios in aggregate with the student-faculty ratio dropping only slightly at public degreegranting universities (16.6 to 16.1 from 1993 to 2013) while student faculty ratios have dropped appreciably at private non-profit colleges and universities (dropping from 12.4 to 10.6 over this interval), which would point broadly toward increasing labor costs absent changes in the composition of faculty. ${ }^{6}$ These findings are generally inconsistent with substitution away from increasingly expensive faculty.

The national increase in faculty salaries misses two dimensions of increased stratification - discipline and research intensity. First, faculty salaries have not risen proportionately across all sectors of higher education and, in Table 1, we distinguish colleges and universities by public control and research intensity, along with faculty rank. Indeed, constant dollar salaries of faculty at community colleges and non-doctorate granting public colleges have actually lost ground at all ranks since the early 1970s, with only modest gains at non- $\mathrm{PhD}$ institutions since $2000 .^{7} \mathrm{In}$ contrast, faculty at research intensive universities ("Research I" in the Carnegie classifications), most notably in the private sector, have made substantial real gains in compensation over the last

\footnotetext{
${ }^{5}$ The original insight derives from the Baumol-Bowen analysis of the performing arts in the 1960s and has been broadly applied to higher education, including in an early study of the economics of private research universities Bowen. Essentially, because higher education is labor-intensive and there are few opportunities for substituting capital for labor, unit labor costs in sectors like higher education and the performing arts will increase more rapidly than in the economy overall (a contemporary discussion can be found in Bowen (2012)). Recognizing that technology is not entirely absent from modern classrooms and characteristics of faculty (including research knowledge) may have adjusted, Bowen (2012) notes that any changes in the quality of teaching are not captured in unit output measures.

${ }^{6}$ See Digest of Education Statistics 2014 (Table 314.10). Note that for public universities there is a substantial cyclical component in student-faculty ratios, with student-faculty ratios rising during recessionary periods (Turner, 2015). What is more, as discussed below, there is substantial evidence of increased stratification or variance in student-faculty ratios over time. Bound, Lovenheim and Turner (2010) show that the most selective institutions experienced declines in student-faculty ratios, while student faculty ratios have risen at many less selective institutions.

${ }^{7}$ Turner (2013) provides a detailed discussion of the divergence between the private and public sector in studentfaculty ratios and hiring during the recessionary period beginning in 2008, along with the widening of differences between research universities and open-access institutions in the public sector.
} 
quarter century. Between 1990 and 2015, salaries of full professors increased, on average, by $23 \%$ at public universities and nearly $44 \%$ at private universities in constant dollar terms. The increased stratification and competition in the market for research faculty is yet more evident when we compare faculty at top-ranked research institutions to the broader set of research universities (also shown in Table 1), where the increase in full professor salaries was about 51\% at the top privates and 31\% at the top publics between 1990 and 2015. Salary increases have been concentrated at the universities where faculty are expected to produce both scholarly research and teaching, and it is the research contributions which are most broadly priced in the national marketplace. An implication is that the price of research has increased at a greater rate than the price of instruction.

The differential changes in faculty salaries across type of institution mirror the wellestablished pattern of increased input stratification across higher education, which is also a reflection of the increased "quality competition" in higher education (Hoxby, 2009). Effectively, just as colleges and universities compete for students, they are also competing for top-tier faculty and greater availability of resources increases an institution's capacity to attract top-tier faculty.

Faculty salaries are also increasingly differentiated by discipline. Doctorate-level faculty are one of the most specialized educational classifications in the labor market. Because the field (and, indeed, subfield) of a $\mathrm{PhD}$ determines employment options, there are few opportunities for "substitution" across disciplines - a unique feature of the academic labor market that we return to shortly. What we see in the available aggregate data $^{8}$ is the increased divergence among fields in compensation: fields like economics, engineering and the physical sciences have higher salaries than those in the humanities and some social sciences like sociology and anthropology.

\footnotetext{
${ }^{8}$ Note that faculty salaries by discipline are not collected as part of the standard IPEDS reporting process and it is thus very difficult to assemble a long time series for a well-defined set of universities.
} 
The first columns of Table 2 present data for public universities that are in the AAU (and participate in a central data exchange) for 2002-03 and 2014-15. While salaries have been fairly stagnant or increased at single-digit rates in a number of fields, including English, and sociology, the discipline of economics defines the other tail with increases of about $30 \%$ across the ranks over this interval. To see faculty salaries over the longer time horizon of nearly four decades, we turn to data assembled on faculty salaries at the broader group of public land grant universities in Figure 2. Over time, the variance in real salaries across disciplines has increased markedly moving from an era in which the better compensated fields received only a modest premium to the current period in which salaries differ by orders of magnitude across fields. As probably more than one exasperated dean has noted, a rookie $\mathrm{PhD}$ economist commands a salary almost twice that of a starting doctorate in English.

Our interest is in how the structure of these differences in salaries across disciplines within research universities links to the organization of instructional activities. At the same time, salaries for faculty within discipline and rank also vary markedly which leads to the question of how faculty with different skill and salary levels are allocated to different instructional and research tasks within the university.

\section{Market Forces and Faculty Salaries}

As with any labor market, the determination of "price" or salary in academics is a function of supply and demand. Thus, for entry-level faculty the only avenue for supply is new doctorate production, while the supply of more senior faculty is constrained by past production. ${ }^{9}$

\footnotetext{
${ }^{9}$ A long research literature, with a particular focus on science and engineering fields, has assessed the particular challenges of projections in doctorate labor markets where the long period for degree attainment creates a substantial lag between program entry and degree receipt. Changes in market demand may then magnify any mismatch between supply and demand of new doctorates in the presence of myopic expectations (see Breneman and Freeman, 1974; Freeman 1976; National Academy of Sciences 2000). The result is that doctorates entering the labor market during weak job markets are likely to receive relatively low starting salaries.
} 
A noteworthy point is that the flow of new doctorates varies in ways that only tangentially mirror the flow of new positions. Figure 3 shows the relative change in new doctorates over the last quarter century by discipline. While computer science and mathematics, which may have considerable non-academic labor markets, ${ }^{10}$ are distinguished by the growth in number of $\mathrm{PhDs}$ awarded, the relatively flat trajectories for the humanities and social sciences are also notable because they occur in the presence of a long-term excess of doctorates relative to academic positions. Considering the contrast between English and economics, the mismatch between new doctorates and new positions would explain much of the recent trend in salaries. Figure 4 shows the divergent trends in new job postings: whereas there is more than one position for each new $\mathrm{PhDs}$ in economics, the situation is reversed in English where the number of jobs relative to PhDs is less than 1 and declining.

The decisions of colleges and universities to add faculty follow from demands for teaching and research, with the latter only a significant factor for a small set of doctorate granting universities. Behind the job postings are basic demand determinants that can be expected to affect how universities choose to allocate hiring across fields. As the labor market and student preferences (both undergraduate and graduate) change, students will choose to pursue different specializations to the extent afforded by the curriculum. Over time, fields like computer science that are known to have large changes in market demand demonstrate substantial cyclical patterns in undergraduate degree receipt. Still, universities may - wisely - be

\footnotetext{
${ }^{10}$ Data from the 2013 Survey of Doctorate Recipients show that about $38 \%$ of computer science doctorates and $43 \%$ of chemistry doctorates are at colleges or universities, while about $73 \%$ of sociology doctorates and $67 \%$ of politics doctorates are employed at colleges and universities.
} 
reluctant to address sharp changes in student demand generated by short-term factors with permanent tenure track hiring. ${ }^{11}$

University goals to increase research output also place upward pressure on the demand for faculty. Fields in which external research funding is relatively plentiful will also experience relative booms in hiring and salaries, as universities aim to compete for federal funds which are not only inputs into rankings but also generate substantial opportunities for cost recovery. Research funding shocks in the last half century have been large and differentiated across specific science disciplines. For the physical sciences, defense investments and federal funding spiked in the 1980s, before reversing in the 1990s and then rebounding somewhat. For the life sciences, the doubling of the NIH budget between 1998 and 2003 contributed to an increase in demand for faculty and salaries of research active faculty, particularly in the life sciences.

Salary increases and reductions (at least in real terms) do not provide the only margin of adjustment to changes in demand in academic labor markets. For faculty at research universities, non-wage compensation often takes the form of benefits intended to increase research productivity. Additional benefits may include funded graduate students and access to money to purchase equipment, travel and data, as well as lower teaching loads and more frequent sabbatical leaves. When these latter forms of compensation are used to compete for faculty they necessarily affect a university's resource allocation in the teaching domain..$^{12}$

\footnotetext{
${ }^{11}$ Johnson and Turner (2009) explore some of the reasons beyond differences in faculty compensation that may limit adjustment to student demand, including the need to maintain a minimum scale in small departments, administrative constraints and curricular requirements intended to temper demand in popular majors.

${ }^{12}$ Writing more than two decades ago, Bowen and Sosa (1989) identify decreasing teaching loads as avenue for adjustment and suggest that direct increases in salary would be a more efficient pathway to labor market clearing. Yet, to the extent that universities may share the benefits of increased research productivity afforded by reduced teaching, incentives may be aligned in compensation arrangements providing the in-kind benefit of reduced teaching.
} 


\section{Faculty Deployment and Faculty Salaries - Sketching a Theoretical Framework}

The market for academic labor that we have just described determines the general pattern of salaries across fields and subfields. Individual universities, their departments, and their faculty have no influence on these general patterns. They are for the most part price takers in the conventional sense, although there may sometimes be cases where the fit between an individual university and faculty member is unusually good (in which case there is some rent to be divided) or unusually bad (in which case there is unlikely to be a long-lasting match).

We assume that the university maximizes an objective function ${ }^{13}$ that depends positively on the quantity and quality of students taught, and the quantity and quality of research. As noted above, we look only at arts and sciences departments, broadly defined to include computer science. In practice, the university has a complicated budget constraint, because it has the possibility of engaging in a variety of activities that can generate revenue in excess of cost (or vice versa). Here we assume that in the background the university has a well-defined budget constraint, and understands the relationships among changes in research and teaching activity, revenue and cost, and the elements of the objective function.

Faculty members each have a utility function defined on salary, leisure, the quality of the work environment, time spent in various activities (e.g., teaching and research), quality of teaching and research and reputation. Faculty tastes vary both within and across fields of expertise, as does faculty skill. That is, within departments, some faculty members are able to produce more or better research and teaching than others, for the same measured input. At a

\footnotetext{
${ }^{13}$ Universities are notorious for their complicated mechanisms of decision-making. Here we assume that the nexus of President, Provost and Dean has solved all of the agency problems at those levels, and has consistent preferences regarding what it would like chairs, faculty members, and everyone else to do, conditional on budget, etc., although that leadership nexus is not assumed to understand, say, the best way to teach physics or decode papyri.
} 
given allocation of time to research and teaching, some faculty would prefer to increase teaching effort and others would prefer to increase research, holding salaries constant.

The university's problem is to deploy its faculty (including both tenure and non tenure track) in a way that maximizes the value of the objective function. To keep the discussion simple, we adopt the conventional rubrics of teaching and research, subscripted by field, and we focus on the deployment of tenure-track faculty. Tenure-track faculty are especially interesting because as a general matter they can (and do) both teach and do research. A key margin regarding deployment of such faculty is the intra-departmental division between teaching and research, which will depend in part on the intradepartmental distribution of skills and tastes. This reasoning directly implies that within a department we should observe that the best researchers should on average teach less than the best teachers (unless the best researchers have sufficiently - and surprisingly -- strong preferences for teaching), where teaching less can be accomplished via course reduction (fewer courses) or less onerous assignments (fewer or students or students who are easier to teach per course).

The trick to evaluating this hypothesis is to measure research quality. In the absence of direct measures of research output, we can use our assumption that the university as a decisionmaker is rational and cares about research reputation. The university values scholarly reputation and scholarly output. It doesn't know how to produce those things, but it is good at finding experts who do know how to produce those things, field-specifically. Those experts are tenuretrack faculty, organized into departments. The university tells the departments to hire great faculty, and by and large it trusts the departments' judgments, in part because the university's goal of having an excellent scholarly reputation is aligned with departmental goals to advance departmental reputation. 
Left to their own devices the departments will hire the best research faculty that they can with the money that they are given, subject (probably) to meeting some minimum requirement for undergraduate teaching quality imposed by the preferences of members of the department, and (almost certainly) by some set of constraints on quality and quantity of undergraduate education imposed by the university. ${ }^{14}$ In particular, the university will often agree to supplement the department's salary and slot budgets in exchange for the department's teaching sufficiently more undergraduates to cover any increase in cost.

Scholarly reputation and output are produced, department by department, via technologies that are black boxes from the perspective of the university. In this setup, it is fairly straightforward to construct a model in which faculty salaries (and the net of other perks, such as graduate vs. undergraduate teaching) within a department should be a good indicator of qualityweighted research output. The marketplace in which field-specific faculty salaries are determined is driven almost entirely by research. Except for the fact that salaries are never reduced in nominal terms, the labor market should produce a set of salaries for tenure-track faculty in each department that give us a ranking (in the happy extreme, an exact measure of value marginal product) of faculty research production.

If salary levels (intra-departmentally only) are good measures of research quality/quantity and research skill isn't strongly positively correlated with a preference for allocating time to

\footnotetext{
${ }^{14}$ Marc Nerlove (1972) constructs a model in which at sufficiently low levels of teaching quantity and quality teaching and research are complements. He draws a production possibility frontier for teaching and research (he includes graduate education as part of research) that has regions near the axes that slope up. In this formulation, even a department that cared only about research would do some teaching. Meanwhile, former Cornell University president Frank Rhodes (1998) asserts that the frontier slopes upward at low amounts of research. He quotes John Slaughter: "Research is to teaching as sin is to confession. If you don't participate in the former you have very little to say in the latter." That these complementarities are evident to university leaders does not necessarily imply that they are evident to individuals or departments. In any case, departments in research universities generally act as if they live in the region where research and teaching are substitutes in production.
} 
teaching, we should observe that highly-paid faculty within a department do relatively little teaching on average and that the teaching that they do has relatively high consumption value, either directly or as an input into research. This is exactly what we find in the empirical work below. ${ }^{15}$

A second margin of choice for faculty deployment is interdepartmental. Noting that undergraduate tuition within the arts and sciences hardly varies by field (Stange, 2015), the university has an interest in economizing on the cost of instruction, which in turn would suggest that it would want to have larger class sizes in fields where faculty are highly paid. But it's not that simple. The technology of teaching varies by field. Literature and other humanities are often taught in ways that require a high level of faculty-student interaction, including provision of extended comments on multiple drafts of papers. Courses in science, math, and some social sciences, meanwhile, can often be organized without expressive writing and associated communication. Thus it's common to see introductory courses in quantitative fields that have hundreds of students, while courses at the same level in the humanities will have 30 students or fewer. The effect of such differences on the instructional cost per student seat can be much larger than the effect of differences (even by factors of two to one) in the average salaries of faculty in different fields. ${ }^{16}$

\footnotetext{
${ }^{15}$ Ron Ehrenberg has pointed out to us that there will be some cases where faculty stars with excellent research reputations can contribute to departmental and university reputations (and perhaps tuition levels) by teaching large undergraduate courses and allowing the institution to claim that undergraduates get to learn from, e.g., Nobel Prize winners. This phenomenon is very much in the spirit of the optimizing framework we have sketched here. Where it occurs it would weaken the negative relationship between research productivity and numbers of undergraduate students taught. Exploring the teaching deployment of "superstars" would be a useful exercise which we leave for future work.

${ }^{16}$ It is also possible that faculty members in lower-paid fields, reflecting the relatively low opportunity cost of their time, are effective in influencing the administration and faculty governance to increase the number of slots in their departments. This hypothesis was suggested in Johnson and Turner (2009) who note the parallel with the finding from the corporate finance literature that weak divisions within firms are known to hold more than their optimal
} 
The technology of effective teaching and learning affects the nature of the game between the university and its departments. In all cases, the department would like to be generously supported in its research ambitions, while the university will generally undertake actions designed to lead the department to take into account the volume and technology of its teaching have on the revenues available to the institution. Thus the total salary pool available to the department will generally depend positively on the number of students taught. To hire better research faculty (which is to say, more expensive faculty) the department must agree to teach more students. This is easier in some fields than in others. Indeed, where small classes are essential to effective teaching, there may be no feasible bargain to be struck that would increase the department's tuition-generated resources.

We note that in some universities there are formal budget models that allocate tuition revenue to academic units, and in others, all or most such revenue is distributed centrally. For our purposes what matters is that the university leadership can see and act upon the connection between teaching activity and tuition revenue, enabling it to negotiate (either directly or via manipulating budgeting formulas) with academic departments regarding faculty salaries, size and workloads. ${ }^{17}$

allocation of cash (from the perspective of shareholders), as the return to internal lobbying may be greater for executives in these units.

${ }^{17}$ See Courant and Knepp (2002) for a discussion of activity-based budgeting. The kind of bargaining that we are talking about here would be facilitated by a system that allocated tuition revenue at the level of the school or college (or the department, although the latter configuration would be unusual, and does not apply at either Michigan or Virginia). For period that we are analyzing in this chapter Michigan allocated tuition revenue to deans, such that the arts and sciences dean was empowered to engage in bargaining with departments, whereas at Virginia the bargain was generally undertaken at a higher level of administration with teaching activity only weakly aligned with schoollevel resources; beginning in 2015, Virginia adopted a new budget model with a resource allocation broadly similar to the Michigan model. 


\section{Empirical Strategy and Data}

Our model of faculty allocation and compensation in university production functions references the circumstances of research universities and, in particular, those disciplines in the arts and sciences, broadly defined. We do not look at professional schools in areas like medicine, law and faculty in these fields (and their assignments) are often separated from central university resource allocation given the generally free-standing pricing, admissions and hiring decisions within these professional schools. ${ }^{18}$

\section{$\underline{\text { Institutional Micro Data }}$}

To examine how variation in compensation affects the allocation of faculty resources in the university context, we look at micro data from two public research universities - the University of Michigan and the University of Virginia. These institutions are broadly representative of AAU universities which are intensive in research, while also producing a significant number of undergraduate and graduate degree recipients. The University of Virginia and the University of Michigan share very competitive undergraduate degree programs that are generally ranked among the top-25 universities nationally, and the top 2 or 3 public universities. The University of Michigan is somewhat larger than the University of Virginia ${ }^{19}$, generates considerably more research funding, and is generally regarded as having a greater number of highly ranked graduate programs. We believe it is reasonable to expect the findings from these universities to apply directly to peer public and private institutions in the AAU, even as there is

\footnotetext{
${ }^{18}$ It is also the case that the compensation of faculty in business schools and medical schools is very different and, especially in medical schools, much more complicated than in arts and sciences fields, so the exclusion of professional schools helps to improve the tractability of the analysis.

${ }^{19}$ In Fall 2014, total enrollment was 43,625 with 28,395 undergraduates at the University of Michigan relative to 23,732 with 16,483 undergraduates at the University of Virginia.
} 
surely some institution-specific variation. It is useful to underscore the observation that individual-level data on faculty salaries at private universities are nearly impossible to obtain, while public universities make such information available on a regular basis.

In an effort to focus the analysis on a finite number of well-defined disciplines, we look at 11 disciplines that constitute separate administrative departments at nearly every research university and draw from the humanities (English, History, Philosophy), the social sciences (Economics, Politics, Sociology, Psychology) and the natural and computational sciences (Math, Physics, Chemistry and Computer Science). These disciplines are intended to span broad differences in types of instruction such as the emphasis on written expression, lab experiences, and quantitative analysis. In addition, there are notable differences among these disciplines in faculty compensation, as well as student demand.

For both the University of Virginia and the University of Michigan, we have combined data on faculty compensation and course-level records of enrollment, which also identify the instructor of record..$^{20}$ For both universities, we are able to record salaries for all regular instructional faculty, which proves to cover the great majority of courses offered. The course level data include the instructor, course title, course type, enrollment level, and course number, which allows for the distinction between graduate and undergraduate courses. For consistency, we focus on traditional "group instruction" courses and do not analyze independent study listings or speaker series ("workshops"). For the University of Michigan, courses and salary data extend from 2002-2015. For the University of Virginia, course offering data extend from the present to 1990 while the faculty salary data are available for only the three most recent years.

\footnotetext{
${ }^{20}$ Data from the University of Michigan were obtained from the Learning Analytics Task Force and from public records of salaries; data for the University of Virginia combine the publicly available faculty salary file with comprehensive "web scraping" of the course offering directory, which was originally conducted by Lou Bloomfield.
} 
There are 52,556 different records from our focal departments from the 1990-91 academic year to 2014-15 for the University of Virginia alone.

The empirical strategy proceeds in two related parts. The first set of questions focuses on department level variation, where we assess differences by discipline and changes over time in teaching allocations in relation to salary levels. The second piece of the analysis examines within department variation in compensation and teaching.

\section{Descriptive Measures}

For the purpose of this analysis, discipline-level variation in faculty salaries is assumed to be exogenous. In turn, we assume that individual faculty salaries are determined on the national market by competitive forces. ${ }^{21}$ To provide a baseline, columns in the right-hand panel of Table 2 shows faculty salaries by rank for the disciplines that are the focus of our analysis for the University of Virginia and the University of Michigan. One broad point is the notable correlation in salaries across fields - economics is the most highly paid field while English is consistently at or near the bottom. Secondly, salary differences between the universities are much smaller at the assistant level than the full level, likely reflecting the greater reward for (highly variable) research productivity among the full professors. Overall, between-university differences in compensation reflect in part differences in the "ranking" or research productivity of departments. While faculty in English and History receive broadly similar compensation, faculty in sociology are far better compensated at the University of Michigan than at the University of Virginia, reflecting both the higher research ranking and greater quantitative focus of the Michigan

\footnotetext{
${ }^{21}$ Beyond faculty productivity, some differences in compensation between the University of Michigan and the University of Virginia may reflect differential program quality or compensating differences associated with the different geographic regions.
} 
department. ${ }^{22}$ Table 3 illustrates some of the differences between the universities in rankings and research measures.

In terms of the program offerings, our focal departments all award both undergraduate and doctorate degrees. Again, there are some differences reflective of the overall institutional scale (the University of Michigan is larger than the University of Virginia), but there are similarities in terms of variations across disciplines in scale and the relative representation of graduate and undergraduate students.

\section{Empirical Evidence}

\section{$\underline{\text { Between Department Analysis }}$}

Teaching students is, perhaps, the most easily recognized "output" of an academic unit, with this coin of the realm often captured in measures of student enrollment or student credit hours. ${ }^{23}$ Our interest is in the alignment between the faculty inputs and the courses taught between departments within universities. Table 4 shows the distribution of course seats in total and relative to the overall faculty counts. The provision of course seats relative to faculty headcount varies markedly across departments for both universities. Still, the "tails" of the distributions are quite similar between the two institutions: English has the lowest student course enrollment to faculty ratio at 35.2 for Virginia and 30.5 for Michigan, while chemistry and economics are disciplines near the top with student course enrollment to faculty ratios 4-5 times

\footnotetext{
${ }^{22}$ Indeed, the finding that between-institution variation in faculty compensation within disciplines is linked to variation in faculty research productivity between institutions follows the more general result from Ehrenberg, McGraw, and Mrdjenovic (2006).

${ }^{23}$ While many universities have adopted budget models which tie revenue flows to enrollment ("RCM"), few such models allow for decentralization and incentives at the level of the individual department, but instead limit incentives to the school level.
} 
higher at both institutions. Were faculty similarly priced across disciplines, such differences would create enormous differences in the cost of instruction across fields.

When we shift to thinking about expenditures on faculty relative to courses and students taught the picture shifts dramatically. A rudimentary indicator of average cost of a course offering in a department is the total faculty salary bill relative to course seats taught. ${ }^{24}$ Table 5 shows two measures which portray similar evidence: the first column includes all faculty including those on leave, while the second only includes those actively teaching in 2014-15. What we see is a very dramatic narrowing - and in some cases reversal -- of the relative differences among departments in the cost-per student, while departments with the highest salary levels are not those with the greatest cost of educational delivery. Two disciplines merit a particular focus. English is an outlier on the high end for both Virginia $(\$ 2,837)$ and Michigan $(\$ 2,393)$. In contrast, economics - which has the highest average salaries, is near the bottom of the distribution of cost of course-seat provision.

Figure 5 illustrates the central finding that overall salary levels are negatively correlated with the cost of providing a course seat across disciplines. This finding is consistent with our theoretical prediction that universities adjust to variation in input costs by altering the organization of teaching. A corollary to this point is that we would expect faculty costs per seat to change by less than discipline-specific changes in faculty salaries over time.

It is worth noting that the consequences for educational quality of compensating for higher salaries via larger class sizes will vary as a function of the way in which disciplines produce and share knowledge. In humanities fields it is often the case that being able to express

\footnotetext{
${ }^{24}$ Of course, faculty are compensated for research as well as teaching. This metric is appropriate to the extent that the research share of faculty compensation is the same across departments. To the extent that research shares are larger in the most highly compensated departments, these measures will overstate the teaching costs in relatively research-intensive departments.
} 
knowledge is inextricably bound up with the knowledge itself, in which case good pedagogy requires substantial writing (or filming, or podcast-creating) with careful evaluating and editing on the part of the instructor. In contrast, many more quantitative fields can be taught and assessed without close interaction among the material, the student, and the instructor. We expect that in all cases it is possible to increase class sizes at the cost of reducing educational quality. However the terms of the tradeoff may differ greatly by field.

To test the hypothesis that the technology of teaching differs across disciplines in ways that may limit class size expansion and the organization of classroom activities, we coded syllabi from 6 fields (English, economics, history, philosophy, physics, and psychology) at the University of Virginia and the University of Michigan. Our sample is effectively one of convenience as we chose randomly conditional on the availability of syllabi with the aim of coding one course at the introductory, intermediate and upper levels of course offerings. We present some examples in Table 6 and some basic intuitive points are clear: introductory courses are generally larger than upper level courses, some disciplines (particularly economics and psychology) have relatively large courses. Other points suggestive of differences in "technology" are apparent in the grading and writing requirements. In economics and physics, the majority of the evaluation is based on examination while writing is minimal. In English, history and philosophy, writing and participation components of evaluation are the norm. We summarize these results in the regressions results shown in Table 7: both discipline and course scale have an appreciable effect on outcomes such as the percent of the grade determined by examination and whether writing or participation are part of the evaluation. Our favored interpretation is that variation in the nature of the material and the nature of learning across disciplines drives these results. 


\section{$\underline{\text { Intra-departmental analysis }}$}

In section three we hypothesized that, within departments, research-productivity should be negatively correlated with faculty teaching effort and that we could use salary as a measure of research productivity. That is, controlling for rank, and recognizing that the market for faculty at this level is determined largely by research reputation, we would expect a negative relationship between salary and teaching activity within a department.

We controlled for rank by running the regression on full professors only. Variation in the salaries of assistant professors generally derives from accidents of history. The starting salary in the year of hire is determined in the relevant marketplace, and salaries then move according to budgetary circumstances. In our experience it's unusual for differences in assistant professor salaries to reflect much else. Associate professors come in two flavors. Some are progressing nicely towards a second promotion, and if we could identify these it would be sensible to include them in the model with a control for their rank. Unfortunately, the other flavor of associate professor is progressing slowly if at all, and a model that describes their salary behavior well does not fit the first flavor of associate professor. Based on these considerations and our theoretical discussion of the expected power of salary as an indicator of research quality, we limit our empirical analysis to full professors, whose salaries are likely to reflect current or recent market circumstances.

Table 8 reports the effects of salary (in 2014 dollars) and departmental fixed effects (the omitted department is History) on the numbers of courses and students taught, using UM data from 2002 to $2014 .^{25}$ The regression also included fixed effects for each year (except 2002). The regression confirms quite powerfully our prediction regarding salary and teaching. The

\footnotetext{
${ }^{25}$ Results for the University of Virginia are qualitatively similar though somewhat less precisely estimated given a shorter panel of salary data.
} 
magnitudes are not trivial. The coefficients on salary reported in the table are in thousands of dollars, implying that an increase in salary of $\$ 10 \mathrm{k}$ leads to a reduction in the number of undergraduate courses of about five percent of a course per year, and a reduction in the number of undergraduate students by about 3.5 per year. The results suggest that superstars whose salary is $\$ 100 \mathrm{k}$ more than the mean teach half an undergrad course less and about 35 fewer undergraduate students. For some departments, 35 undergraduates per full professor per year is more than the average load. Additionally, the coefficients for graduate students and graduate courses are positive and significant, consistent with the idea that graduate teaching has amenity value for faculty, or is part of the production of research, or, most likely, both in some combination.

The regression reported on in Table 8 and the preceding paragraph looks at all faculty and controls for departmental differences via departmental fixed effects. In Table 9, we organize the analysis somewhat differently, running separate regressions for each department at Michigan (with year fixed-effects, as in Table 9). As before, there is a consistent and generally significant negative relationship between full professor salaries within departments and the number of undergraduate students and courses taught in that department. In this formulation, we also see clearly that there is substantial variation in the slope of the relationship. In Psychology, Economics, and Chemistry $\$ 10,000$ in annual salary is associated with a reduction of about six students per year. In Philosophy and History our estimate is about a third the size, and in English and Sociology $\$ 10,000$ in pay is associated with a reduction of less than 1.5 students per year. As in our earlier specification, the numbers of undergrads taught falls with full professor salaries, while the number of graduate students taught rises. These patterns are also evident in Figure 6, 
which multiplies the estimates by 50 , showing the changes in students taught associated with a $\$ 50,000$ difference in salary.

\section{Conclusion and Thoughts Ahead}

Tenure track faculty in research universities teach and they do research. Over the past several decades, the relative prices - in terms of wages paid to faculty - of those two activities have changed markedly. The price of research has gone up way more than the price of teaching. Salaries have risen much more in elite research universities than in universities generally. This is quite consistent with models in which compensation depends on tournaments and rankings, and the most successful workers can command a substantial premium relative to those who are merely successful (Lazear and Rosen, 1981; Rosen, 1986; Rosen, 1981).

Departments in research universities (the more so the more elite) must pay high salaries in order to employ research-productive faculty. These faculty, in turn, contribute most to the universities' goals (which include teaching as well as research) by following their comparative advantage and teaching less, and also teaching in ways that are complementary with research notably graduate courses. The university pays these faculty well because they are especially good at research. It makes perfect sense that they would also have relatively low teaching loads (along with relatively high research expectations, which we don't observe directly.)

In addition to deploying faculty productively within departments, the university has an interest in providing its curriculum efficiently - which is to say, at the lowest cost consistent with other desiderata, including quality and the ability to produce tuition revenue. The two most important features that relate to faculty deployment across departments are faculty salaries and class sizes. We observe large differences in both, with the faculty in the highest-paid 
departments tending to have the largest average class sizes, resulting in "cost per seat" being essentially uncorrelated with salaries for the departments we have studied at Michigan and Virginia.

A striking finding at both institutions is that the cost per seat is much higher in English than in any other department, notwithstanding the fact that salaries in English are at the low end of the distribution. As a matter of arithmetic, this is the result of relatively small class sizes in English. Why are class sizes there so small? We expect that it's because the technology of teaching and learning in English (and, plausibly, in other fields where detailed interpretation of text is an essential part of what is to be learned) is such that it is difficult or impossible to teach effectively in large classes. This is in contrast to, say, economics or chemistry, where learning what is in the text book, and working on relatively well-defined problems, is much easier to scale up.

To be sure, economists would also like to teach small classes, both introductory and advanced, but they also like to have strong colleagues across the discipline. The loss in teaching quality and the amenity value of teaching associated with teaching large introductory sections (and large advanced courses) is easily worth the gain of paying (and being paid) what the market requires for good faculty. ${ }^{26}$ Based on our analysis in Table 9, that tradeoff is on average less salutary in the humanities. Our analysis shows that departments in which close engagement with text is likely to be an essential part of teaching and evaluation relies on interpretation (writing, presentation) face lower tradeoffs between increases in salary and reductions in students taught.

\footnotetext{
${ }^{26}$ A related adjustment that may be adopted by departments with high salaries combined with teaching demands is further division of labor between faculty conducting research and those conducting teaching to include the appointment of "master teachers" to teach core and introductory classes (Figlio, Schapiro, and Soter, 2015).
} 
If we accept that the value placed on research in elite research university is warranted, we conclude that the deployment of faculty is generally consistent with rational behavior on the part of those universities. Faculty salaries vary, for a variety of reasons, and the universities respond to that variation by economizing on the most expensive faculty, while attending to differences in teaching technologies across fields. 


\section{References}

Autor, David. 2014. "Skills, Education, and the Rise of Earnings Inequality Among the "Other 99 Percent” Science, 23 May 2014: 344 (6186), 843-851.

Bound, John; Michael Lovenheim and Sarah Turner. 2010. "Why have college completion rates declined? An analysis of changing student preparation and collegiate resources." American Economic Journal: Applied Economics.

Bowen, William. 2012 "Cost Trends, the "Cost Disease," and Productivity in Higher Education" The Tanner Lectures Stanford University http://www.ithaka.org/sites/default/files/files/ITHAKA-TheCostDiseaseinHigherEducation.pdf

Bowen, William G. 2013. "Academia Online: Musings (Some Unconventional)." http://ithaka.org/sites/default/files/files/ithaka-stafford-lecture-final.pdf

Bowen, William and Julie Ann Sosa. 1989. Prospects for Faculty in the Arts and Sciences. Princeton University Press.

Breneman, David and Richard Freeman. 1974 Forecasting the Ph.D. Labor Market: Pitfalls for Policy, with Richard B. Freeman, Technical Report No. 2, National Board on Graduate Education (Washington, D.C.: National Academy of Sciences Press).

Campos, Paul. 2015. “The Real Reason College Tuition Costs So Much,” New York Times, April 4, 2015, available at www.nytimes.com/2015/04/05/opinion/sunday/ the-real-reason-college-tuition-costs-so-much.html?_r $=0$.

Courant, Paul N. and Marilyn Knepp,"Activity Based Budgeting at the University of Michigan," (with Marilyn Knepp), in Douglas Priest et. al., eds., Incentive-Based Budgeting Systems in Public Universities, Edward Elgar, 2002, pp. 137-160.

Ehrenberg, Ronald, McGraw, Marquise and Mrdjenovic, Jesenka, (2006), Why do field differentials in average faculty salaries vary across universities?, Economics of Education Review, 25, issue 3, p. 241-248.

Figlio, David. Morton Schapiro, Kevin Soter. 2015. Review of Economics and Statistics vol 97, Issue 1: 715-724.

Freeman, Richard. 1976. "A Cobweb Model of the Supply and Starting Salary of New Engineers." Industrial and Labor Relations Review, 29:236-48.

Jacob, Brian; Brian McCall and Kevin Stange. forthcoming. "College as Country Club: Do Colleges Cater to Students' Preferences for Consumption?” Journal of Labor Economics. 
Johnson, William and Sarah Turner. 2009. "Faculty without students: Resource allocation in higher education." The Journal of Economic Perspectives 23 (2), 169-189

Hoxby, Caroline. 2009. "The Changing Selectivity of American Colleges." Journal of Economic Perspectives, 23(4): 95-118. DOI: 10.1257/jep.23.4.95

Lazear, Edward and Sherwin Rosen, 1981. "Rank-Order Tournaments as Optimum Labor Contracts," Journal of Political Economy, 89(5), pp. 841-864

National Academy of Science. 2000. "Forecasting Demand and Supply of Doctoral Scientists and Engineers: Report of a Workshop on Methodology"

Nerlove, Marc. 1972. "On Tuition and the Costs of Higher Education: Prolegomena to a Conceptual Framework." Journal of Political Economy Vol. 80, No. 3, Part 2: Investment in Education: The Equity-Efficiency Quandary (May - Jun., 1972), pp. S178-S218

Rosen, Sherwin. 1981. "The Economics of Superstars", American Economic Review, 71, issue 5, p. $845-58$

Rosen, Sherwin. 1986. "Prizes and Incentives in Elimination Tournaments," American Economic Review, 76(4), pp. 701-715.

Stange, Kevin. 2015. "Differential pricing in undergraduate education: effects on degree production by field." Journal of Policy Analysis and Management 34.1: 107-135.

Sallee James M \& Resch Alexandra M \& Courant Paul N, 2008. "On the Optimal Allocation of Students and Resources in a System of Higher Education," The B.E. Journal of Economic Analysis \& Policy, De Gruyter, vol. 8(1), pages 1-26, June.

Turner, Sarah. 2013. "The Impact of the Financial Crisis on Faculty Labor Markets" in How the Financial Crisis and Great Recession Affected Higher Education. Hoxby and Brown, ed. Chicago: University of Chicago Press. 
Figure 1. Overall Trends in Faculty Salaries by Rank, Constant Dollars (2015\$)

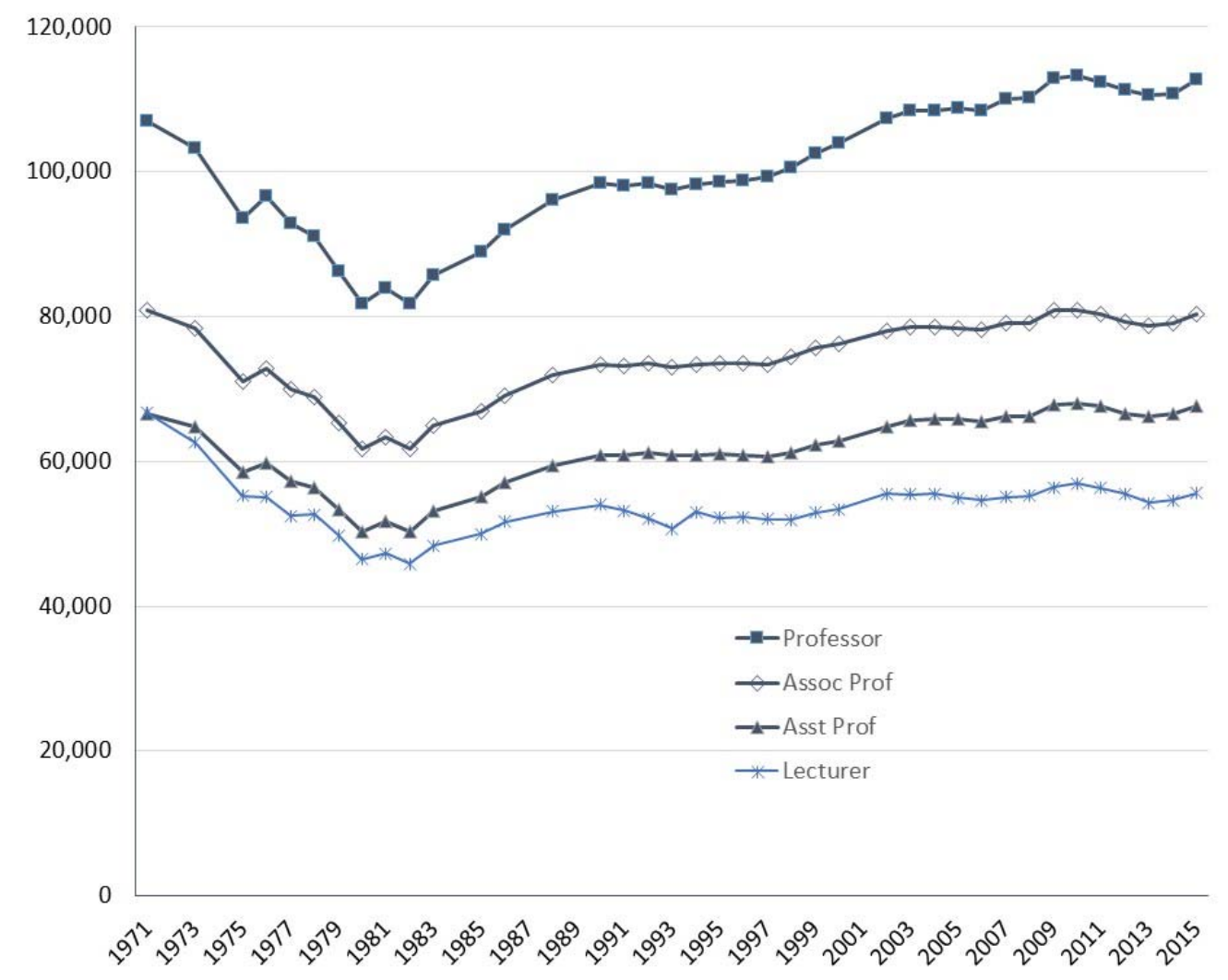

Source: U.S. Department of Education, National Center for Education Statistics, Higher Education General Information Survey (HEGIS), "Faculty Salaries, Tenure, and Fringe Benefits" surveys, 1970-71 through 1985-86; Integrated Postsecondary Education Data System (IPEDS), "Salaries, Tenure, and Fringe Benefits of Full-Time Instructional Faculty Survey" 1987-2015. [See Table 316.10 from 2015 Digest of Education Statistics] 
Figure 2. Faculty salaries by rank and discipline, public universities, constant dollar (2015\$)

\section{Assistant Professors}

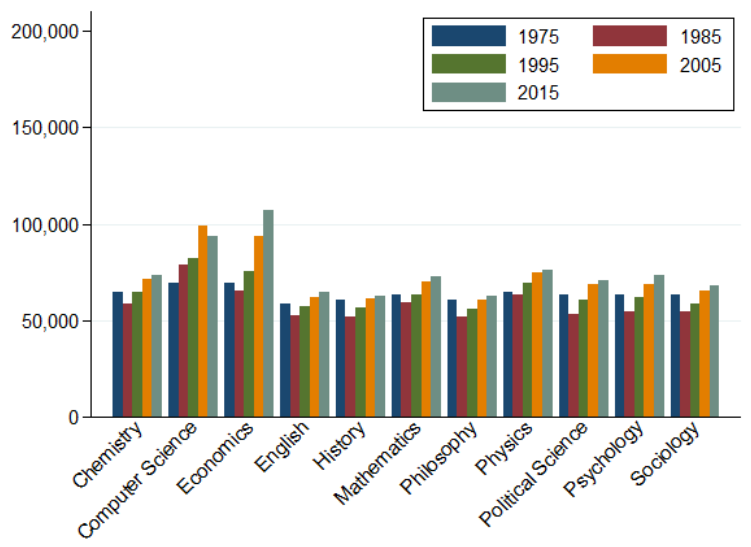

\section{Associate Professors}

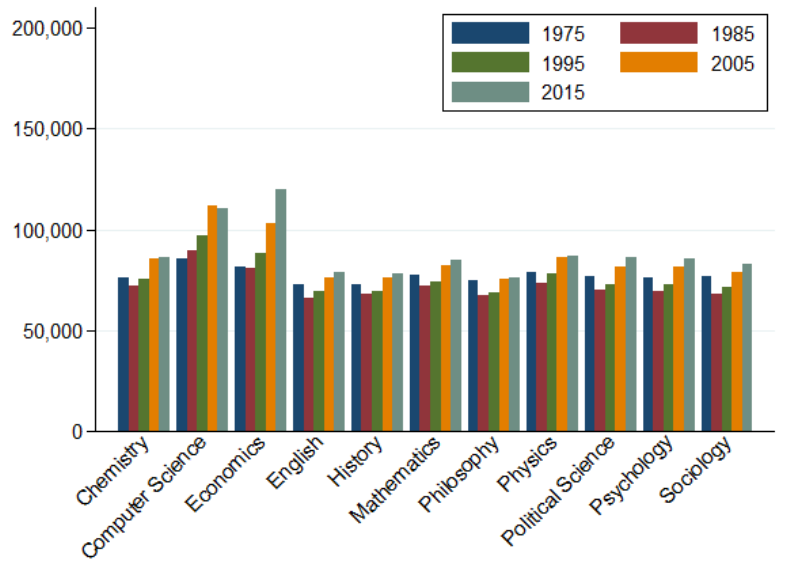

\section{Full Professors}

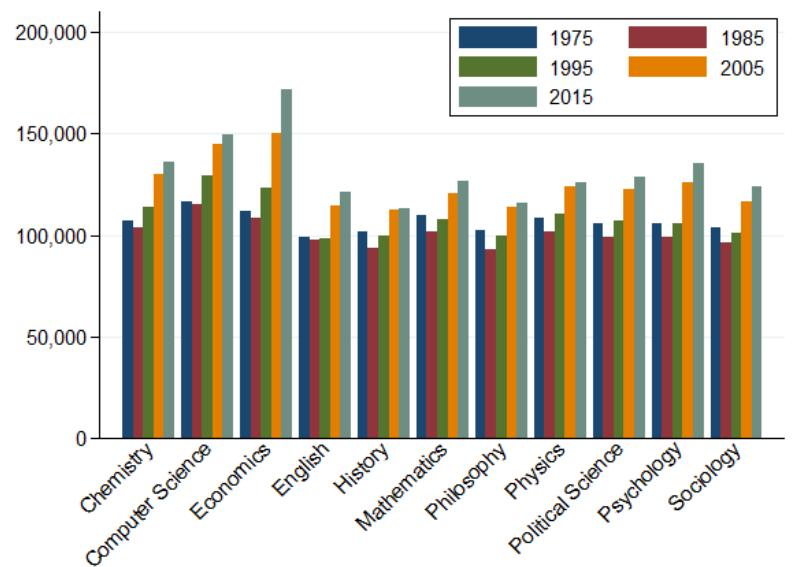

Source: Faculty Salary Survey of Institutions Belonging to NASULGC (Oklahoma State University, Various years). 
Figure 3. Trends in Doctorates Conferred by Discipline (index 2000=100)

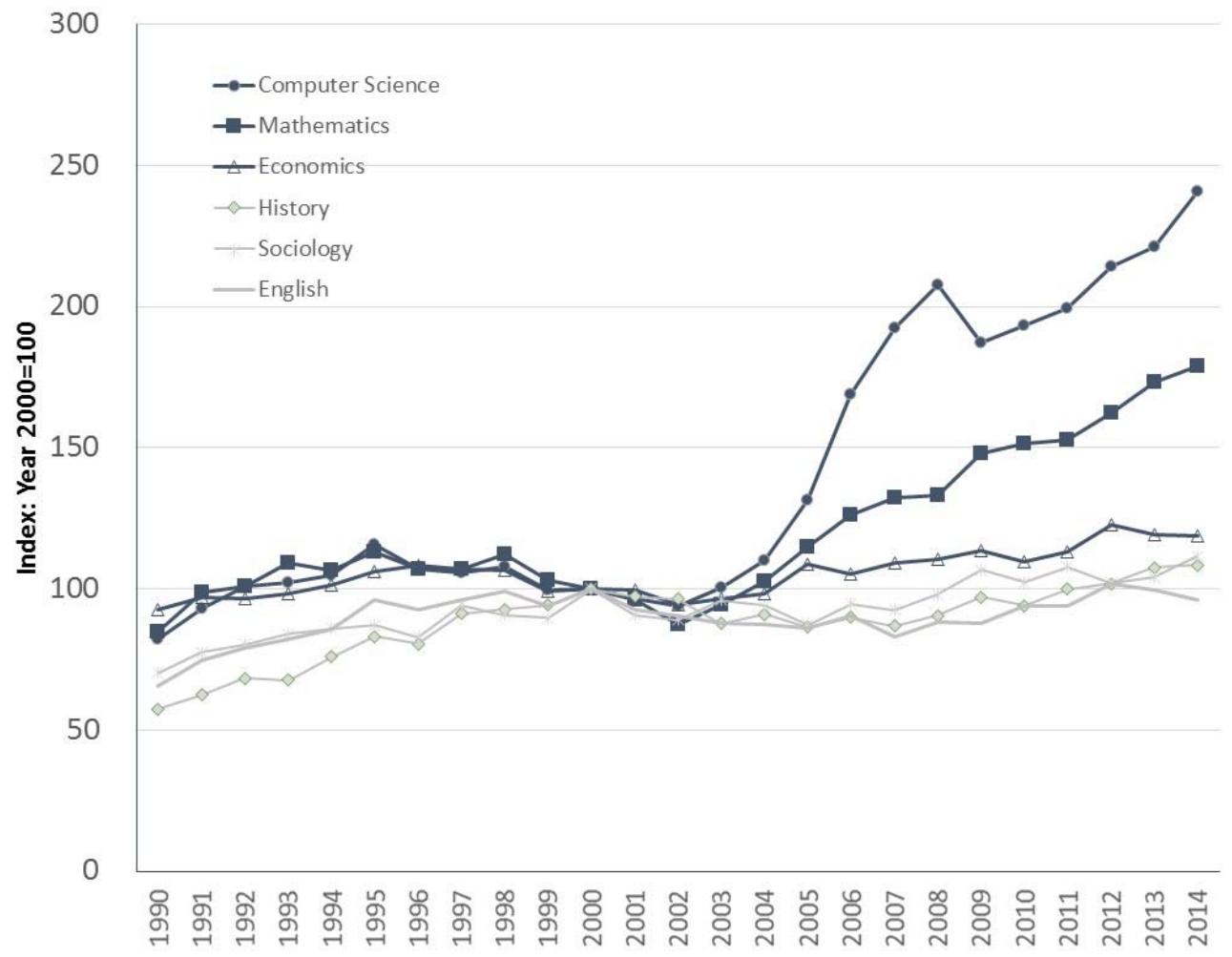

Source: Survey of Earned Doctorates, various years. 
Figure 4. New Job Postings by field relative to new doctorates awarded, 2001-2012

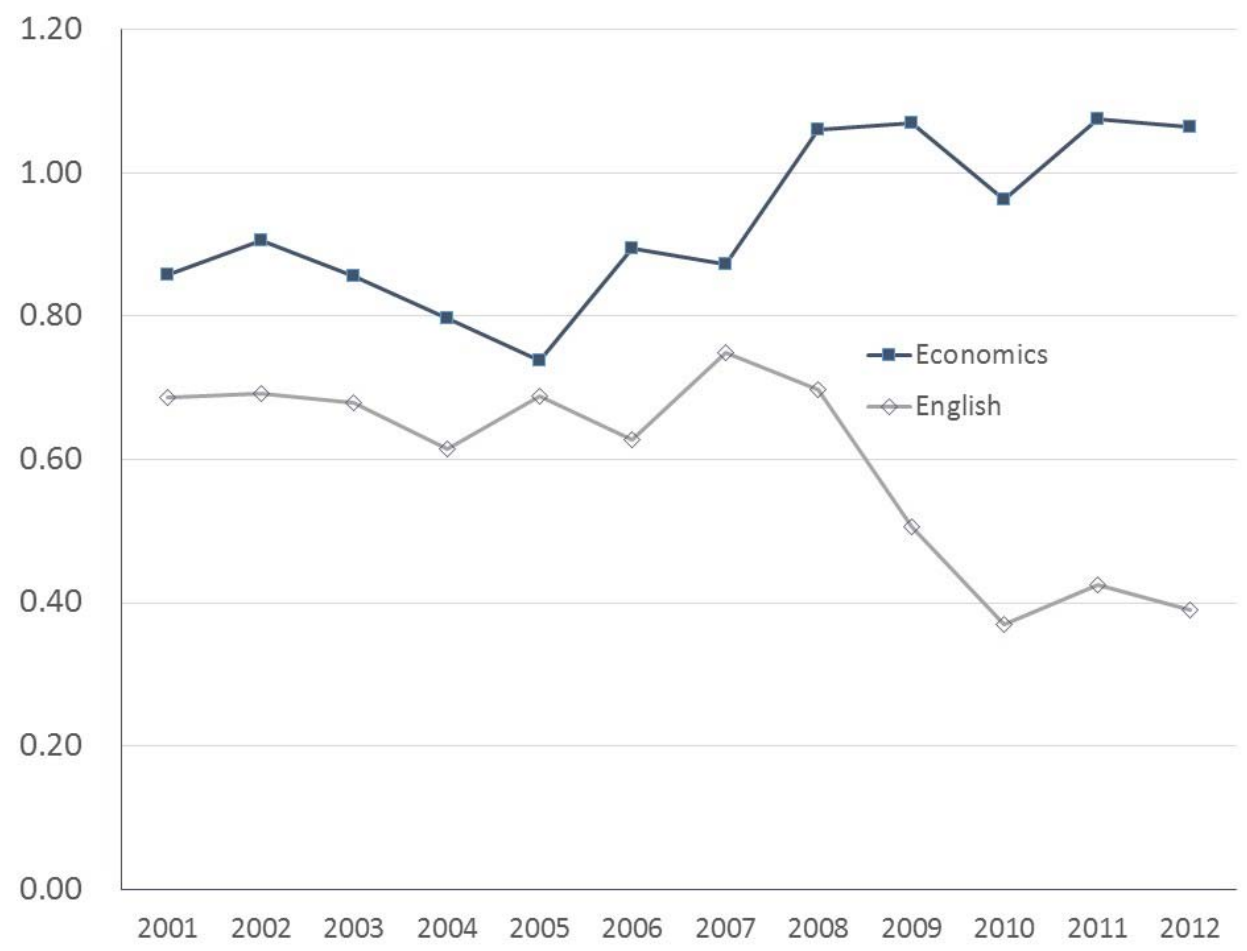

Sources: Authors' tabulations from the American Economics Association and the MLA, with new PhDs by discipline from the Survey of Earned Doctorates. 
Figure 5. Faculty Salaries and Cost Per Seat, University of Virginia and University of Michigan, 2014-15

\section{University of Michigan}

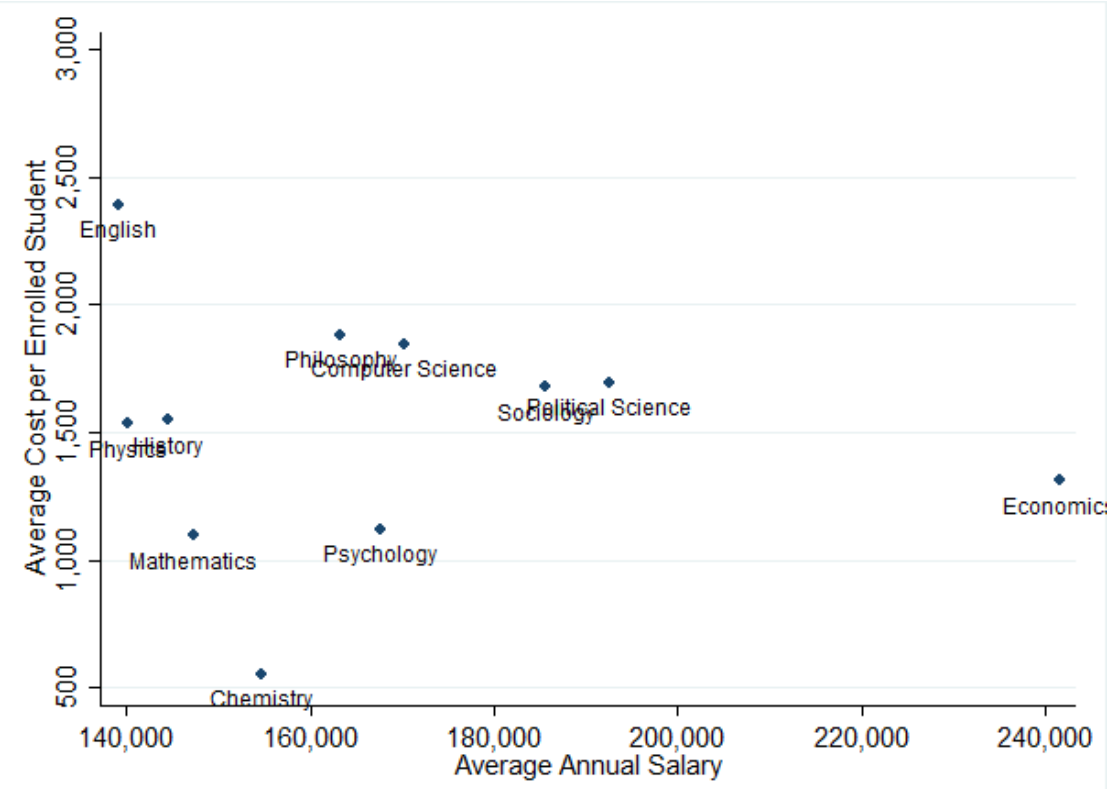

\section{University of Virginia}

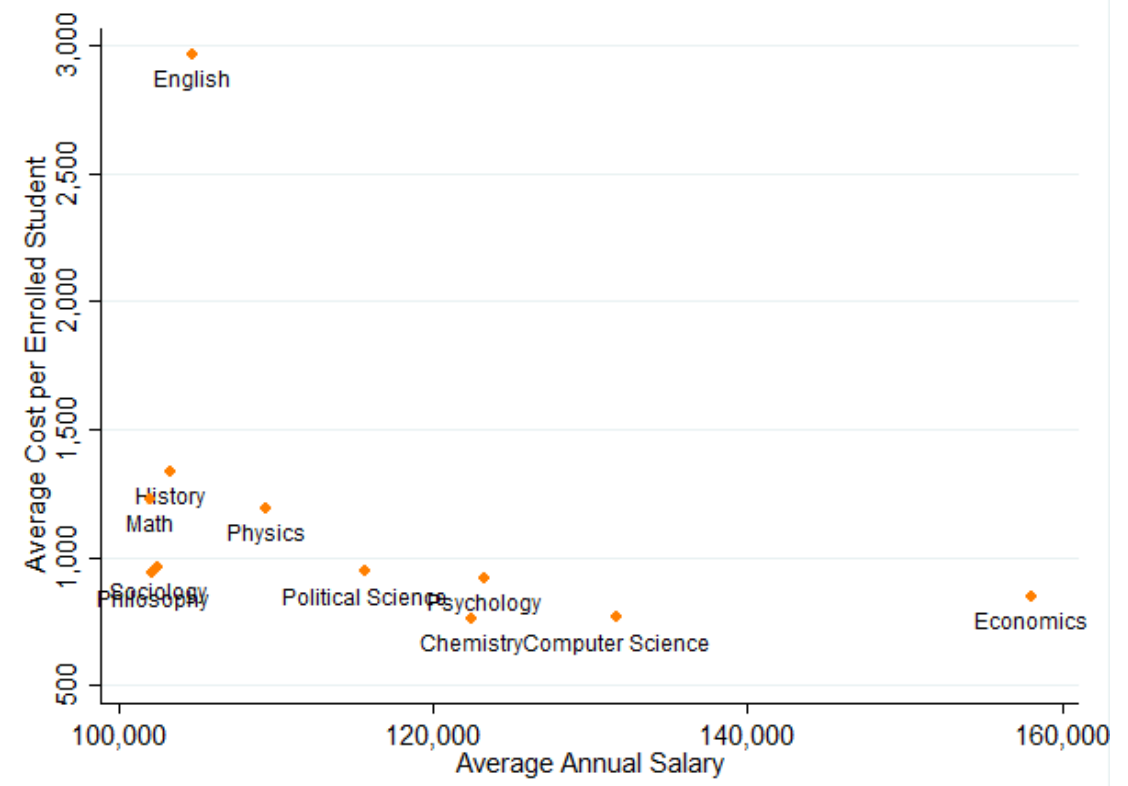

Source: Authors' tabulations. University of Virginia shown in orange, University of Michigan in blue. This version of the table presents the average salary of full professors on the $x$-axis; the next version will use the average salary of all faculty which produces a qualitatively similar presentation. 
Figure 6. Change in Students Taught Within Departments per $\$ \mathbf{5 0 , 0 0 0}$ in Salary

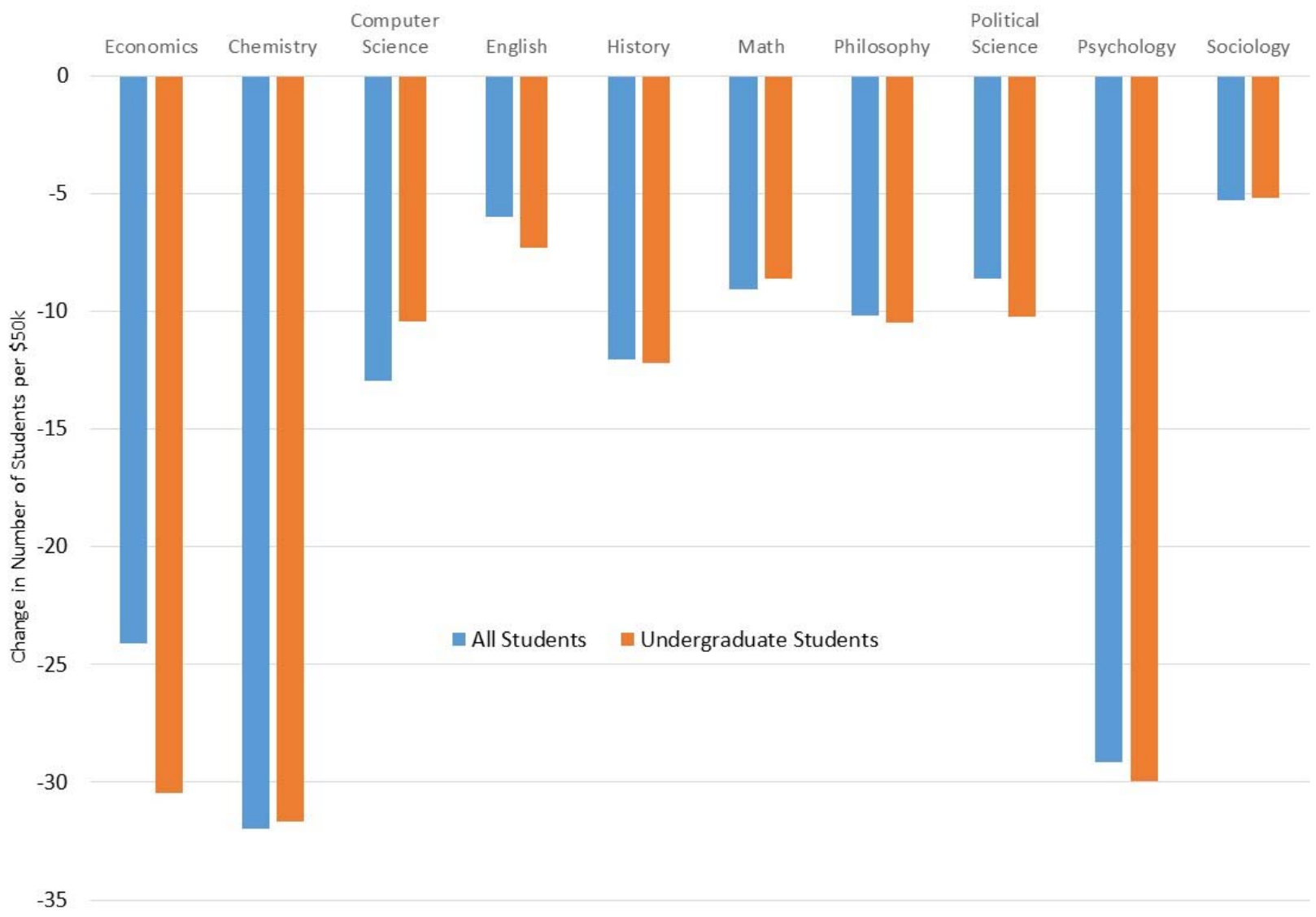

Source: See Table 11. Estimates based on within-department regressions of the effect individual faculty salary on teaching assignment. 
Table 1. Faculty Salaries by Type of Institution, Selected Years, Constant Dollar (2015\$)

\begin{tabular}{lcrrrr} 
& \multicolumn{5}{c}{ Assistant Professor } \\
\cline { 2 - 6 } & 1971 & 1980 & 1990 & 2000 & 2015 \\
\hline Research 1 Public & $\$ 84,336$ & 57,222 & 70,783 & 72,739 & 83,801 \\
Research 1 Private & 73,741 & 54,417 & 73,088 & 84,895 & 101,244 \\
Research 2 Public & 69,565 & 53,191 & 63,012 & 66,126 & 75,930 \\
Other 4 yr Public & 66,251 & 51,484 & 59,807 & 60,746 & 65,810 \\
Other 4 yr Private & 60,355 & 47,508 & 54,007 & 57,812 & 64,160 \\
Priv Liberal Arts 1 & 62,144 & 45,808 & 56,401 & 59,976 & 64,555 \\
2-Year Public & 67,875 & 52,778 & 59,766 & 58,990 & 57,912 \\
& & & & & \\
Top 7 Private Universities & 74,416 & 54,489 & 73,876 & 86,053 & 113,781 \\
Top 5 Public Universities & 70,742 & 56,459 & 74,575 & 80,973 & 95,053
\end{tabular}

Full Professor

\begin{tabular}{lrrrrr}
\cline { 2 - 6 } & \multicolumn{1}{c}{1971} & \multicolumn{1}{c}{1980} & \multicolumn{1}{c}{1990} & \multicolumn{1}{c}{2000} & \multicolumn{1}{c}{2015} \\
\hline Research 1 Public & $\$ 120,131$ & 96,491 & 114,427 & 123,811 & 141,205 \\
Research 1 Private & 127,120 & 101,796 & 129,787 & 149,459 & 186,582 \\
Research 2 Public & 111,328 & 86,409 & 101,954 & 109,547 & 125,028 \\
Other 4 yr Public & 102,313 & 82,779 & 93,081 & 95,076 & 99,348 \\
Other 4 yr Private & 89,032 & 76,390 & 84,731 & 90,721 & 100,941 \\
Priv Liberal Arts 1 & 95,940 & 71,853 & 89,804 & 99,558 & 106,659 \\
2-Year Public & 90,788 & 87,329 & 91,645 & 80,683 & 75,507
\end{tabular}

$\begin{array}{llllll}\text { Top } 7 \text { Private Universities } & 131,690 & 107,058 & 141,430 & 166,396 & 213,495\end{array}$

\begin{tabular}{llllll} 
Top 5 Public Universities & 125,591 & 102,229 & 128,886 & 144,801 & 168,710 \\
\hline
\end{tabular}

Source: Authors' tabulations using Source: U.S. Department of Education, National Center for Education Statistics, Higher Education General Information Survey (HEGIS), "Faculty Salaries, Tenure, and Fringe Benefits" surveys, 1970-71 through 1985-86; Integrated Postsecondary Education Data System (IPEDS), "Salaries, Tenure, and Fringe Benefits of Full-Time Instructional Faculty Survey" 1987-2015. The top 7 private universities are coded as: Princeton, Harvard, Yale, Columbia, Stanford, Chicago, MIT. The top 5 public universities are coded as: UC-Berkeley, UCLA, University of Virginia, University of Michigan, UNCChapel Hill. 
Table 2. Faculty salaries by discipline and rank, AAUDE Public universities, the University of Michigan, and the University of Virginia (2015 \$)

Full Professors

\begin{tabular}{|c|c|c|c|c|c|}
\hline \multirow[b]{3}{*}{ Department } & \\
\hline & \multicolumn{5}{|c|}{ AAU Public Aggregate } \\
\hline & 2002-03 & 2014-15 & $\%$ Change & $\begin{array}{c}\text { University of } \\
\text { Virginia }\end{array}$ & $\begin{array}{c}\text { University of } \\
\text { Michigan }\end{array}$ \\
\hline Chemistry & $\$ 139,450$ & $\$ 148,698$ & $6.6 \%$ & $\$ 149,832$ & $\$ 154,673$ \\
\hline Computer Science & $\$ 146,690$ & $\$ 154,647$ & $5.4 \%$ & $\$ 183,127$ & $\$ 170,329$ \\
\hline Economics & $\$ 156,965$ & $\$ 202,347$ & $28.9 \%$ & $\$ 186,250$ & $\$ 241,464$ \\
\hline English & $\$ 116,228$ & $\$ 123,480$ & $6.2 \%$ & $\$ 125,578$ & $\$ 139,149$ \\
\hline History & $\$ 121,106$ & $\$ 126,459$ & $4.4 \%$ & $\$ 130,594$ & $\$ 144,650$ \\
\hline Mathematics & $\$ 125,957$ & $\$ 134,605$ & $6.9 \%$ & $\$ 141,877$ & $\$ 147,399$ \\
\hline Philosophy & $\$ 127,274$ & $\$ 138,665$ & $8.9 \%$ & $\$ 115,260$ & $\$ 163,305$ \\
\hline Physics & $\$ 129,609$ & $\$ 137,162$ & $5.8 \%$ & $\$ 129,117$ & $\$ 140,172$ \\
\hline Political Science & $\$ 133,944$ & $\$ 148,812$ & $11.1 \%$ & $\$ 149,147$ & $\$ 192,633$ \\
\hline Psychology & $\$ 132,491$ & $\$ 138,617$ & $4.6 \%$ & $\$ 151,530$ & $\$ 167,564$ \\
\hline Sociology & $\$ 127,758$ & $\$ 137,473$ & $7.6 \%$ & $\$ 136,213$ & $\$ 185,634$ \\
\hline & \multicolumn{5}{|c|}{ Assistant Professors } \\
\hline & \multicolumn{3}{|c|}{ AAU Public Aggregate } & & \\
\hline Department & $2002-03$ & 2014-15 & $\%$ Change & $\begin{array}{c}\text { University of } \\
\text { Virginia }\end{array}$ & $\begin{array}{c}\text { University of } \\
\text { Michigan }\end{array}$ \\
\hline Chemistry & $\$ 76,330$ & $\$ 83,527$ & $9.4 \%$ & $\$ 78,400$ & $\$ 84,792$ \\
\hline Computer Science & $\$ 103,438$ & $\$ 98,563$ & $-4.7 \%$ & $\$ 126,567$ & $\$ 100,974$ \\
\hline Economics & $\$ 94,614$ & $\$ 119,563$ & $26.4 \%$ & $\$ 123,538$ & $\$ 124,948$ \\
\hline English & $\$ 64,891$ & $\$ 69,153$ & $6.6 \%$ & $\$ 69,267$ & $\$ 71,149$ \\
\hline History & $\$ 65,513$ & $\$ 70,146$ & $7.1 \%$ & $\$ 69,280$ & $\$ 74,478$ \\
\hline Mathematics & $\$ 72,471$ & $\$ 84,659$ & $16.8 \%$ & $\$ 85,500$ & $\$ 60,298$ \\
\hline Philosophy & $\$ 65,631$ & $\$ 71,825$ & $9.4 \%$ & $\$ 66,000$ & $\$ 108,981$ \\
\hline Physics & $\$ 79,831$ & $\$ 85,613$ & $7.2 \%$ & $\$ 85,733$ & $\$ 90,140$ \\
\hline Political Science & $\$ 73,701$ & $\$ 82,838$ & $12.4 \%$ & $\$ 87,100$ & $\$ 89,417$ \\
\hline Psychology & $\$ 72,190$ & $\$ 78,906$ & $9.3 \%$ & $\$ 96,700$ & $\$ 87,124$ \\
\hline Sociology & $\$ 71,077$ & $\$ 77,203$ & $8.6 \%$ & $\$ 66,388$ & $\$ 90,524$ \\
\hline
\end{tabular}

Source: Authors' tabulations from AAUDE institutional data from public universities and institutional public-release files for the University of Virginia and the University of Michigan. 
Table 3. Comparative Characteristics by Discipline, University of Virginia and university of Michigan

\begin{tabular}{|c|c|c|c|c|c|c|}
\hline Program Name & $\begin{array}{l}\text { U.S. News } \\
\text { Ranking }\end{array}$ & $\begin{array}{c}\text { Average } \\
\text { Citations per } \\
\text { Publication }\end{array}$ & $\begin{array}{l}\text { Percent of } \\
\text { Faculty with } \\
\text { Grants, } \\
2006\end{array}$ & $\begin{array}{c}\text { Average } \\
\text { Number of } \\
\text { Ph.D.s } \\
\text { Graduated, } \\
\text { 2002-2006 }\end{array}$ & $\begin{array}{c}\text { Average GRE } \\
\text { Scores, } \\
\text { 2004-2006 }\end{array}$ & $\begin{array}{c}\text { Tenured } \\
\text { Faculty as a } \\
\text { Percent of } \\
\text { Total Faculty, } \\
2006\end{array}$ \\
\hline & \multicolumn{6}{|c|}{ University of Michigan-Ann Arbor } \\
\hline Chemistry & 15 & 2.49 & $84.0 \%$ & 31.20 & 732 & $86.0 \%$ \\
\hline Computer Science & 13 & $\mathrm{~N} / \mathrm{D}$ & $81.6 \%$ & 17.40 & 800 & $83.0 \%$ \\
\hline Economics & 13 & 1.86 & $54.9 \%$ & 15.00 & 791 & $73.0 \%$ \\
\hline English Language \& Lit. & 13 & $N / D$ & $11.5 \%$ & 8.20 & 716 & $84.0 \%$ \\
\hline History & 7 & $N / D$ & $17.6 \%$ & 16.40 & 654 & $90.0 \%$ \\
\hline Mathematics & 9 & 1.03 & $84.8 \%$ & 14.40 & 800 & $86.0 \%$ \\
\hline Philosophy & & $N / D$ & $16.2 \%$ & 4.20 & 699 & $84.0 \%$ \\
\hline Physics & 11 & 2.56 & $88.3 \%$ & 12.60 & 793 & $84.0 \%$ \\
\hline Political Science & 4 & 1.87 & $54.7 \%$ & 14.00 & 718 & $86.0 \%$ \\
\hline Psychology & 4 & 3.52 & $66.4 \%$ & 25.60 & 728 & $83.0 \%$ \\
\hline \multirow[t]{2}{*}{ Sociology } & 4 & 2.66 & $50.0 \%$ & 11.40 & 724 & $83.0 \%$ \\
\hline & \multicolumn{6}{|c|}{ University of Virginia } \\
\hline Chemistry & 49 & 2.54 & $62.6 \%$ & 16.60 & 715 & $93.0 \%$ \\
\hline Computer Science & 29 & $N / D$ & $75.0 \%$ & 4.40 & 789 & $64.0 \%$ \\
\hline Economics & 30 & 1.23 & $34.8 \%$ & 8.20 & 783 & $52.0 \%$ \\
\hline English Language \& Lit. & 10 & $N / D$ & $15.9 \%$ & 12.40 & 697 & $90.0 \%$ \\
\hline History & 20 & $N / D$ & $17.9 \%$ & 14.20 & 657 & $90.0 \%$ \\
\hline Mathematics & 52 & 0.71 & $65.1 \%$ & 4.80 & 792 & $79.0 \%$ \\
\hline Philosophy & & $N / D$ & $15.4 \%$ & 1.40 & 676 & $92.0 \%$ \\
\hline Physics & 44 & 2.46 & $87.9 \%$ & 7.40 & 779 & $66.0 \%$ \\
\hline Politics & 36 & 0.47 & $25.0 \%$ & 9.20 & 699 & $86.0 \%$ \\
\hline Psychology & 26 & 2.77 & $80.6 \%$ & 10.80 & 722 & $65.0 \%$ \\
\hline Sociology & 35 & 0.95 & $46.2 \%$ & 4.40 & 674 & $59.0 \%$ \\
\hline
\end{tabular}

Source: U.S. News and World Report and National Academies of Science "Assessment of Research and Doctoral Programs" (2010) 
Table 4. Student Course Enrollment relative to Faculty Staffing, 2014-15

University of Virginia

\begin{tabular}{|c|c|c|c|c|c|c|}
\hline \multirow[b]{2}{*}{ Field } & \multicolumn{3}{|c|}{ Enrollment } & \multicolumn{3}{|c|}{ Student-Course/Faculty Ratio: } \\
\hline & Total & Undergraduate & Graduate & Total & Undergraduate & Graduate \\
\hline Chemistry & 4,990 & 4,580 & 410 & 161.0 & 147.7 & 13.2 \\
\hline Computer Science & 5,688 & 5,278 & 410 & 172.4 & 159.9 & 12.4 \\
\hline Economics & 6,533 & 6,237 & 296 & 186.7 & 178.2 & 8.5 \\
\hline English & 1,727 & 1,608 & 119 & 35.2 & 32.8 & 2.4 \\
\hline History & 3,869 & 3,811 & 58 & 77.4 & 76.2 & 1.2 \\
\hline Math & 2,656 & 2,088 & 568 & 83.0 & 65.3 & 17.8 \\
\hline Philosophy & 1,852 & 1,572 & 15 & 108.9 & 92.5 & 0.9 \\
\hline Physics & 2,749 & 2,509 & 240 & 91.6 & 83.6 & 8.0 \\
\hline Political Science & 4,529 & 4,425 & 104 & 122.4 & 119.6 & 2.8 \\
\hline Psychology & 5,352 & 5,187 & 165 & 133.8 & 129.7 & 4.1 \\
\hline \multirow[t]{4}{*}{ Sociology } & 2,131 & 2,082 & 49 & 106.6 & 104.1 & 2.5 \\
\hline & \multicolumn{6}{|c|}{ University of Michigan } \\
\hline & \multicolumn{3}{|c|}{ Enrollment } & \multicolumn{3}{|c|}{ Student-Course/Faculty Ratio: } \\
\hline & Total & Undergraduate & Graduate & Total & Undergraduate & Graduate \\
\hline Chemistry & 10,067 & 9,672 & 395 & 193.6 & 186.0 & 7.6 \\
\hline Computer Science & 8,125 & 6,430 & 1,695 & 71.9 & 56.9 & 15.0 \\
\hline Economics & 7,320 & 6,429 & 891 & 120.0 & 105.4 & 14.6 \\
\hline English & 3,325 & 2,998 & 327 & 30.5 & 27.5 & 3.0 \\
\hline History & 5,112 & 5,031 & 81 & 56.8 & 55.9 & 0.9 \\
\hline Math & 10,123 & 8,967 & 1,156 & 82.3 & 72.9 & 9.4 \\
\hline Philosophy & 1,786 & 1,722 & 64 & 63.8 & 61.5 & 2.3 \\
\hline Physics & 4,290 & 4,026 & 264 & 71.5 & 67.1 & 4.4 \\
\hline Political Science & 3,691 & 3,416 & 275 & 67.1 & 62.1 & 5.0 \\
\hline Psychology & 11,848 & 11,423 & 425 & 108.7 & 104.8 & 3.9 \\
\hline Sociology & 2,758 & 2,522 & 237 & 86.2 & 78.8 & 7.4 \\
\hline
\end{tabular}

Source: Authors' tabulations. 
Table 5. Estimated Faculty Cost per Seat, University of Michigan and University of Virginia, 2014-15

\section{University of Virginia}

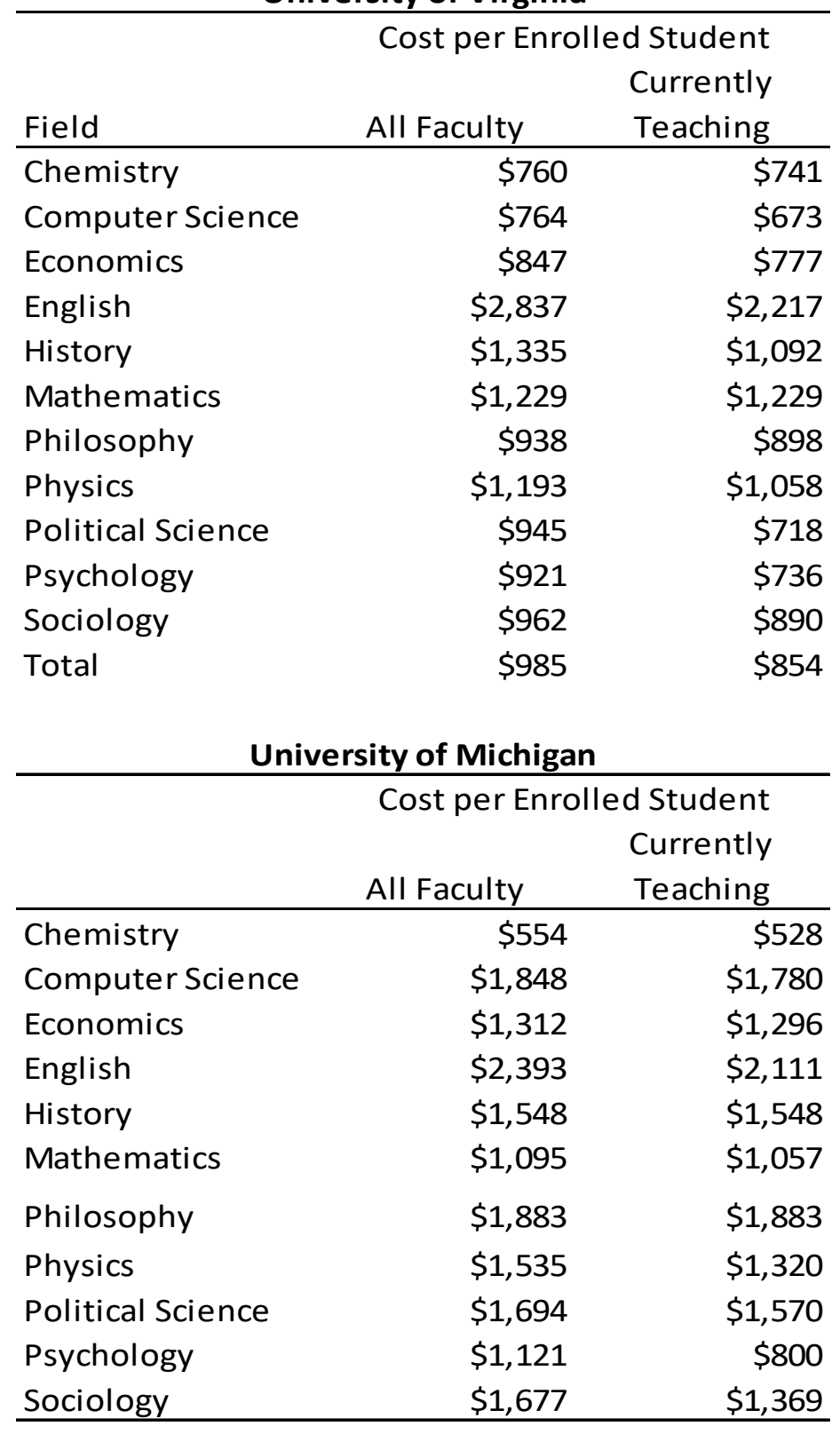

Source: Authors' tabulations. 
Table 6. Field-specific examples of requirements in undergraduate courses

Paper /

Participate/ Exam counts Writing counts

\begin{tabular}{|c|c|c|c|c|c|c|c|c|c|}
\hline Name & Title & Instructor Rank & Enrollment & Exam $(0,1)$ & Writing $(0,1)$ & ) present $(0,1)$ & for $>50 \%$ & for $>50 \%$ & \\
\hline University of Virgir & & & & & & & & & \\
\hline ECON 2010 & Principles of Microeconomics & Lecturer & 298 & & 0 & 0 & & 1 & 0 \\
\hline ECON 3030 & Money and Banking & Assistant Prof. & 83 & & 0 & 0 & & 1 & 0 \\
\hline ECON 4210 & International Trade: Theory and Policy & Professor & 17 & & 1 & 1 & & 1 & 0 \\
\hline ENMC 4530 & J. M. Coetzee in His Times & Associate Prof. & 9 & & 1 & 1 & & 0 & 1 \\
\hline ENNC 3110 & English Poetry and Prose of the Nineteenth Century & Professor & 19 & & 1 & 1 & & 0 & 1 \\
\hline ENRN 3250 & Milton: Origins, Transgressions, Revolutions & Associate Prof. & 29 & & 1 & 0 & & 0 & 1 \\
\hline HIEU 2101 & Jewish History I: The Ancient and Medieval Experience & Associate Prof. & 40 & & 1 & 1 & & 0 & 0 \\
\hline HIEU 3390 & Nazi Germany & Lecturer & 61 & & 1 & 1 & & 1 & 0 \\
\hline HIST 4501 & Scandals in History & Associate Prof. & 8 & & 1 & 1 & & 0 & 1 \\
\hline PHIL 2450 & Philosophy of Science & Professor & 7 & & 1 & 0 & & 0 & 1 \\
\hline PHIL 3710 & Ethics & Professor & 20 & & 1 & 0 & & 0 & 1 \\
\hline PHIL 3999 & Philosophical Perspectives on Liberty & Professor & 25 & & 1 & 0 & & 1 & 0 \\
\hline PHYS 2620 & Modern Physics & Professor & 84 & & 0 & 0 & & 1 & 0 \\
\hline PSYC 2150 & Introduction to Cognition & Associate Prof. & 334 & & 1 & 0 & & 1 & 0 \\
\hline PSYC 3410 & Abnormal Psychology & Professor & 290 & & 1 & 0 & & 1 & 0 \\
\hline PSYC 4110 & Psycholinguistics & Associate Prof. & 22 & & 1 & 1 & & 0 & 0 \\
\hline University of Michi & & & & & & & & & \\
\hline ECON 101-200 & Principles of Economics I-Microeconomics & Lecturer & 322 & & 0 & 0 & & 1 & 0 \\
\hline ECON 310-001 & Money and Banking & Lecturer & 184 & & 0 & 0 & & 1 & 0 \\
\hline ECON 340-001 & $\begin{array}{l}\text { International Economics } \\
\text { Introduction to Literary Studies: Shakespeare, Race, and }\end{array}$ & Professor & 105 & & 0 & 0 & & 1 & 0 \\
\hline ENGLISH 298-007 & $\begin{array}{l}\text { the 20th Century } \\
\text { Topics in Literary Studies: The Road Trip in American }\end{array}$ & Professor & 22 & & 1 & 1 & & 0 & 1 \\
\hline ENGLISH 313-010 & Literature & Professor & 68 & & 1 & 1 & & 0 & 1 \\
\hline ENGLISH 451-001 & Literature $1600-1830$ & Professor & 28 & & 0 & 1 & & 0 & 0 \\
\hline HISTORY 105-001 & Introduction to Religion: From Rastafari to the Sun Dance & Professor & 43 & & 1 & 1 & & 1 & 0 \\
\hline HISTORY 214-001 & Modern Europe & Associate Prof. & 29 & & 1 & 1 & & 0 & 0 \\
\hline HISTORY 386-001 & The Holocaust: The Fate of Jews, 1933-1949 & Professor & 89 & & 1 & 1 & & 0 & 0 \\
\hline HISTORY 451-001 & Japan's Modern Transformations & Associate Prof. & 26 & & 1 & 1 & & 0 & 0 \\
\hline PHIL 180-001 & Introductory Logic & Associate Prof. & 131 & & 0 & 1 & & 1 & 0 \\
\hline PHIL 355-001 & Contemporary Moral Problems & Associate Prof. & 130 & & 1 & 1 & & 0 & 1 \\
\hline PHIL 361-001 & Ethics & Professor & 49 & & 1 & 1 & & 0 & 0 \\
\hline PHYSICS 240-100 & General Physics II & Professor & 147 & & 0 & 0 & & 1 & 0 \\
\hline PHYSICS 340-001 & Waves, Heat, and Light & Assistant Prof. & 29 & & 0 & 0 & & 1 & 0 \\
\hline PHYSICS 401-001 & Intermediate Mechanics & Assistant Prof. & 40 & & 0 & 0 & & 1 & 0 \\
\hline PSYCH 240-020 & Introduction to Cognitive Psychology & Lecturer & 293 & & 0 & 0 & & 1 & 0 \\
\hline PSYCH 250-020 & Human Development & Lecturer & 285 & & 1 & 1 & & 1 & 0 \\
\hline PSYCH 438-001 & Hormones and Behavior & Associate Prof. & 131 & & 0 & 1 & & 1 & 0 \\
\hline
\end{tabular}


Table 7. Association between course requirements and class size and department

\begin{tabular}{|c|c|c|c|c|}
\hline Explanatory Vars. & $\begin{array}{c}(1) \\
\text { Exam Pct } \\
\end{array}$ & $\begin{array}{c}\text { (2) } \\
\text { Writing Pct }\end{array}$ & $\begin{array}{c}(3) \\
\text { Writing }(1 / 0) \\
\end{array}$ & $\begin{array}{c}(4) \\
\text { Participate / } \\
\text { Present }(1 / 0)\end{array}$ \\
\hline Enrollment & $\begin{array}{c}0.000668^{* * *} \\
(0.000211)\end{array}$ & $\begin{array}{l}-0.000230 \\
(0.000152)\end{array}$ & $\begin{array}{l}-0.000964^{*} \\
(0.000489)\end{array}$ & $\begin{array}{l}-0.000858 \\
(0.000596)\end{array}$ \\
\hline Economics & $\begin{array}{l}0.366^{* * *} \\
(0.0937)\end{array}$ & $\begin{array}{c}-0.437^{* * *} \\
(0.0946)\end{array}$ & $\begin{array}{c}-0.609^{* * *} \\
(0.168)\end{array}$ & $\begin{array}{l}-0.377 \\
(0.227)\end{array}$ \\
\hline English & $\begin{array}{l}-0.317^{* * *} \\
(0.0742)\end{array}$ & $\begin{array}{c}0.144 \\
(0.0949)\end{array}$ & $\begin{array}{c}0.130 \\
(0.0826)\end{array}$ & $\begin{array}{l}0.0852 \\
(0.178)\end{array}$ \\
\hline History & $\begin{array}{l}-0.0169 \\
(0.0884)\end{array}$ & $\begin{array}{l}-0.164^{*} \\
(0.0928)\end{array}$ & $\begin{array}{l}0.0114 \\
(0.113)\end{array}$ & $\begin{array}{l}0.260^{*} \\
(0.136)\end{array}$ \\
\hline Physics & $\begin{array}{c}0.181 \\
(0.111)\end{array}$ & $\begin{array}{c}-0.410^{* * *} \\
(0.109)\end{array}$ & $\begin{array}{c}-0.732^{* * *} \\
(0.124)\end{array}$ & $\begin{array}{c}-0.725^{* * *} \\
(0.136)\end{array}$ \\
\hline Psychology & $\begin{array}{l}0.213^{*} \\
(0.111)\end{array}$ & $\begin{array}{c}-0.311^{\star \star \star} \\
(0.116)\end{array}$ & $\begin{array}{l}-0.233 \\
(0.205)\end{array}$ & $\begin{array}{r}-0.0614 \\
(0.215)\end{array}$ \\
\hline UM & $\begin{array}{c}0.0151 \\
(0.0524)\end{array}$ & $\begin{array}{l}-0.00936 \\
(0.0524)\end{array}$ & $\begin{array}{l}-0.217^{* *} \\
(0.0835)\end{array}$ & $\begin{array}{l}0.183^{*} \\
(0.0970)\end{array}$ \\
\hline Constant & $\begin{array}{l}0.369^{* * *} \\
(0.0703)\end{array}$ & $\begin{array}{l}0.517^{* * *} \\
(0.0799)\end{array}$ & $\begin{array}{l}1.067^{* * *} \\
(0.0680)\end{array}$ & $\begin{array}{c}0.634^{* * *} \\
(0.173)\end{array}$ \\
\hline $\begin{array}{l}\text { Observations } \\
\text { R-squared }\end{array}$ & $\begin{array}{c}68 \\
0.722\end{array}$ & $\begin{array}{c}68 \\
0.630\end{array}$ & $\begin{array}{c}68 \\
0.648\end{array}$ & $\begin{array}{c}68 \\
0.531\end{array}$ \\
\hline
\end{tabular}

Source: Philosophy is the omitted department. Convenience sample of 68 courses in 6 disciplines at he University of Virginia and the University of Michigan. 
Table 8. Within Department Determinants of Courses and Students Taught, University of Michigan

Notes:

\begin{tabular}{|c|c|c|c|c|c|c|}
\hline VARIABLES & $\begin{array}{c}\text { (1) } \\
\text { All courses }\end{array}$ & $\begin{array}{c}\text { (2) } \\
\text { Under } \\
\text { courses }\end{array}$ & $\begin{array}{c}\text { (3) } \\
\text { Grad } \\
\text { courses }\end{array}$ & $\begin{array}{c}(4) \\
\text { All } \\
\text { students }\end{array}$ & $\begin{array}{c}\text { (5) } \\
\text { Under } \\
\text { students }\end{array}$ & $\begin{array}{c}\text { (6) } \\
\text { Grad } \\
\text { students }\end{array}$ \\
\hline & & & & - & & \\
\hline Salary (000s) & $\begin{array}{c}-0.00461^{* * *} \\
(0.000319)\end{array}$ & $\begin{array}{c}-0.00568^{* * *} \\
(0.000319)\end{array}$ & $\begin{array}{c}0.00107^{* * *} \\
(0.000229)\end{array}$ & $\begin{array}{l}0.343^{* * *} \\
(0.0264)\end{array}$ & $\begin{array}{c}-0.354^{* * *} \\
(0.0270)\end{array}$ & $\begin{array}{r}0.0114^{* * *} \\
(0.00333)\end{array}$ \\
\hline Comp Sci & $\begin{array}{l}0.140 * * \\
(0.0685)\end{array}$ & $\begin{array}{c}-0.287^{* * *} \\
(0.0655)\end{array}$ & $\begin{array}{c}0.427^{* * *} \\
(0.0391)\end{array}$ & $\begin{array}{l}-0.628 \\
(4.023)\end{array}$ & $\begin{array}{c}-14.43^{* * *} \\
(4.063)\end{array}$ & $\begin{array}{c}13.80 * * * \\
(0.819)\end{array}$ \\
\hline Chemistry & $\begin{array}{c}-0.131 \\
(0.0941)\end{array}$ & $\begin{array}{c}-0.452^{* * *} \\
(0.0858)\end{array}$ & $\begin{array}{l}0.321^{* * *} \\
(0.0564)\end{array}$ & $\begin{array}{c}35.86^{* * *} \\
(10.41)\end{array}$ & $\begin{array}{c}30.61^{* * *} \\
(10.45)\end{array}$ & $\begin{array}{c}5.250 * * * \\
(0.692)\end{array}$ \\
\hline Economics & $\begin{array}{c}0.673 * * * \\
(0.104)\end{array}$ & $\begin{array}{c}-0.153 * * \\
(0.0753)\end{array}$ & $\begin{array}{c}0.826 * * * \\
(0.0754)\end{array}$ & $\begin{array}{c}43.93^{* * *} \\
(8.001) \\
-\end{array}$ & $\begin{array}{c}31.06^{* * *} \\
(7.989)\end{array}$ & $\begin{array}{c}12.87^{* * *} \\
(1.325)\end{array}$ \\
\hline Math & $\begin{array}{c}0.202 * * * \\
(0.0704)\end{array}$ & $\begin{array}{c}-0.479 * * * \\
(0.0665)\end{array}$ & $\begin{array}{c}0.681^{* * *} \\
(0.0445)\end{array}$ & $\begin{array}{c}13.54 * * * \\
(4.107)\end{array}$ & $\begin{array}{c}-25.43 * * * \\
(4.155)\end{array}$ & $\begin{array}{c}11.90 * * * \\
(0.689)\end{array}$ \\
\hline Philosophy & $\begin{array}{c}0.390 * * * \\
(0.0985)\end{array}$ & $\begin{array}{l}0.210^{* *} \\
(0.0926)\end{array}$ & $\begin{array}{c}0.181^{* * *} \\
(0.0536)\end{array}$ & $\begin{array}{l}-0.426 \\
(5.255)\end{array}$ & $\begin{array}{l}-1.481 \\
(5.254)\end{array}$ & $\begin{array}{c}1.054 * * * \\
(0.357)\end{array}$ \\
\hline Physics & $\begin{array}{c}-0.525^{* * *} \\
(0.0768)\end{array}$ & $\begin{array}{c}-0.540 * * * \\
(0.0739)\end{array}$ & $\begin{array}{c}0.0151 \\
(0.0407)\end{array}$ & $\begin{array}{c}24.20^{* * *} \\
(4.218)\end{array}$ & $\begin{array}{c}-27.81^{* * *} \\
(4.250)\end{array}$ & $\begin{array}{c}3.604 * * * \\
(0.632)\end{array}$ \\
\hline Politics & $\begin{array}{c}0.307^{* * *} \\
(0.0910)\end{array}$ & $\begin{array}{c}-0.204 * * * \\
(0.0774)\end{array}$ & $\begin{array}{l}0.511^{* * *} \\
(0.0493)\end{array}$ & $\begin{array}{c}48.52^{* * *} \\
(8.055)\end{array}$ & $\begin{array}{c}42.87 * * * \\
(8.044)\end{array}$ & $\begin{array}{c}5.653^{* * *} \\
(0.511)\end{array}$ \\
\hline Psychology & $\begin{array}{l}-0.165^{* *} \\
(0.0789)\end{array}$ & $\begin{array}{c}-0.595^{* * *} \\
(0.0685)\end{array}$ & $\begin{array}{c}0.430 * * * \\
(0.0473)\end{array}$ & $\begin{array}{c}5.457 \\
(5.486)\end{array}$ & $\begin{array}{c}1.010 \\
(5.493)\end{array}$ & $\begin{array}{c}4.447^{* * *} \\
(0.459)\end{array}$ \\
\hline Sociology & $\begin{array}{c}0.147 \\
(0.117)\end{array}$ & $\begin{array}{c}-0.423 * * * \\
(0.0887)\end{array}$ & $\begin{array}{c}0.569 * * * \\
(0.0689)\end{array}$ & $\begin{array}{c}-7.399 \\
(5.283) \\
-\end{array}$ & $\begin{array}{c}-14.94 * * * \\
(5.040)\end{array}$ & $\begin{array}{c}7.539 * * * \\
(0.885)\end{array}$ \\
\hline English & $\begin{array}{l}-0.169 * * \\
(0.0844)\end{array}$ & $\begin{array}{c}-0.455^{* * *} \\
(0.0776)\end{array}$ & $\begin{array}{c}0.286 * * * \\
(0.0402)\end{array}$ & $\begin{array}{c}21.47^{* * *} \\
(5.803) \\
-\end{array}$ & $\begin{array}{c}-25.09 * * * \\
(5.819)\end{array}$ & $\begin{array}{c}3.615^{* * *} \\
(0.341)\end{array}$ \\
\hline Other & $\begin{array}{c}-1.053^{* * *} \\
(0.0656)\end{array}$ & $\begin{array}{c}-0.882^{* * *} \\
(0.0604)\end{array}$ & $\begin{array}{c}-0.171^{* * *} \\
(0.0318)\end{array}$ & $\begin{array}{c}18.85^{* * *} \\
(4.445)\end{array}$ & $\begin{array}{c}-18.66^{* * *} \\
(4.448)\end{array}$ & $\begin{array}{l}-0.191 \\
(0.381)\end{array}$ \\
\hline Constant & $\begin{array}{c}2.552 * * * \\
(0.0916)\end{array}$ & $\begin{array}{c}2.302^{* * *} \\
(0.0860)\end{array}$ & $\begin{array}{c}0.250 * * * \\
(0.0562)\end{array}$ & $\begin{array}{c}105.4^{* * *} \\
(6.186)\end{array}$ & $\begin{array}{c}104.8^{* * *} \\
(6.238)\end{array}$ & $\begin{array}{c}0.593 \\
(0.793)\end{array}$ \\
\hline Observations & 5,351 & 5,351 & 5,351 & 5,351 & 5,351 & 5,351 \\
\hline R-squared & 0.158 & 0.138 & 0.140 & 0.075 & 0.076 & 0.124 \\
\hline
\end{tabular}

Robust standard errors in parentheses

$* * * p<0.01, * * p<0.05, * p<0.1$

Notes: Faculty-level data recording salary, courses taught and number of students for academic years 2002-03 to 2014-15 for the University of Michigan. Regressions include year fixed effects. 
Table 9. Field-specific within-field regressions of teaching assignment on salary, University of Michigan

\begin{tabular}{|c|c|c|c|c|c|c|}
\hline & (1) & $\begin{array}{c}\text { (2) } \\
\text { Undergraduate } \\
\text { Courses }\end{array}$ & $\begin{array}{c}\text { (3) } \\
\text { Graduate } \\
\text { Courses }\end{array}$ & All Students & $\begin{array}{c}\text { (5) } \\
\text { Undergraduate } \\
\text { Students }\end{array}$ & $\begin{array}{l}\text { (6) } \\
\text { Graduate } \\
\text { Students }\end{array}$ \\
\hline Economics & $\begin{array}{l}-0.000147 \\
(0.00134)\end{array}$ & $\begin{array}{c}-0.00774 * * * \\
(0.000846)\end{array}$ & $\begin{array}{c}0.00759 * * * \\
(0.00100)\end{array}$ & $\begin{array}{c}-0.482^{* * *} \\
(0.119)\end{array}$ & $\begin{array}{c}-0.609 * * * \\
(0.119)\end{array}$ & $\begin{array}{l}0.127 * * * \\
(0.0205)\end{array}$ \\
\hline Chemistry & $\begin{array}{c}-0.00622 * * * \\
(0.00127)\end{array}$ & $\begin{array}{c}-0.00532 * * * \\
(0.00136)\end{array}$ & $\begin{array}{l}-0.000903^{*} \\
(0.000530)\end{array}$ & $\begin{array}{c}-0.639 * * * \\
(0.186)\end{array}$ & $\begin{array}{c}-0.633^{* * *} \\
(0.189)\end{array}$ & $\begin{array}{r}-0.00598 \\
(0.00855)\end{array}$ \\
\hline Computer Science & $\begin{array}{c}-0.00474 * * * \\
(0.000781)\end{array}$ & $\begin{array}{c}-0.00413^{* * *} \\
(0.000749)\end{array}$ & $\begin{array}{l}-0.000602 \\
(0.000623)\end{array}$ & $\begin{array}{c}-0.259 * * * \\
(0.0448)\end{array}$ & $\begin{array}{c}-0.209 * * * \\
(0.0480)\end{array}$ & $\begin{array}{c}-0.0496 * * * \\
(0.0137)\end{array}$ \\
\hline English & $\begin{array}{r}-0.000609 \\
(0.00184)\end{array}$ & $\begin{array}{c}-0.00420 * * * \\
(0.00162)\end{array}$ & $\begin{array}{c}0.00359 * * * \\
(0.000881)\end{array}$ & $\begin{array}{c}-0.120 \\
(0.0846)\end{array}$ & $\begin{array}{l}-0.146^{*} \\
(0.0847)\end{array}$ & $\begin{array}{l}0.0260 * * * \\
(0.00882)\end{array}$ \\
\hline History & $\begin{array}{c}-0.00778 * * * \\
(0.00116)\end{array}$ & $\begin{array}{c}-0.00772 * * * \\
(0.00108)\end{array}$ & $\begin{array}{c}-5.59 e-05 \\
(0.000495)\end{array}$ & $\begin{array}{c}-0.241 * * * \\
(0.0464)\end{array}$ & $\begin{array}{c}-0.244 * * * \\
(0.0460)\end{array}$ & $\begin{array}{c}0.00292 \\
(0.00323)\end{array}$ \\
\hline Math & $\begin{array}{c}-0.00680 * * * \\
(0.00143)\end{array}$ & $\begin{array}{c}-0.00554 * * * \\
(0.00171)\end{array}$ & $\begin{array}{l}-0.00127^{*} \\
(0.000752)\end{array}$ & $\begin{array}{c}-0.181^{*} \\
(0.109)\end{array}$ & $\begin{array}{l}-0.172 \\
(0.116)\end{array}$ & $\begin{array}{c}-0.00883 \\
(0.0162)\end{array}$ \\
\hline Philosophy & $\begin{array}{l}-0.00494^{*} \\
(0.00251)\end{array}$ & $\begin{array}{c}-0.00526^{* *} \\
(0.00210)\end{array}$ & $\begin{array}{l}0.000322 \\
(0.00151)\end{array}$ & $\begin{array}{c}-0.204^{*} \\
(0.112)\end{array}$ & $\begin{array}{l}-0.210^{*} \\
(0.112)\end{array}$ & $\begin{array}{l}0.00616 \\
(0.0100)\end{array}$ \\
\hline Political Science & $\begin{array}{l}-0.00111 \\
(0.00131)\end{array}$ & $\begin{array}{c}-0.00417^{* * *} \\
(0.000965)\end{array}$ & $\begin{array}{c}0.00306 * * * \\
(0.000726)\end{array}$ & $\begin{array}{l}-0.172 \\
(0.128)\end{array}$ & $\begin{array}{l}-0.205 \\
(0.126)\end{array}$ & $\begin{array}{l}0.0331 * * * \\
(0.00778)\end{array}$ \\
\hline Psychology & $\begin{array}{c}-0.00774 * * * \\
(0.00106)\end{array}$ & $\begin{array}{c}-0.00967 * * * \\
(0.000917)\end{array}$ & $\begin{array}{c}0.00194 * * * \\
(0.000747)\end{array}$ & $\begin{array}{c}-0.583^{* * *} \\
(0.0809)\end{array}$ & $\begin{array}{c}-0.599 * * * \\
(0.0808)\end{array}$ & $\begin{array}{l}0.0163 * * \\
(0.00763)\end{array}$ \\
\hline Sociology & $\begin{array}{c}-0.00425^{* * *} \\
(0.00111)\end{array}$ & $\begin{array}{c}-0.00354^{* * *} \\
(0.000724)\end{array}$ & $\begin{array}{l}-0.000703 \\
(0.000748)\end{array}$ & $\begin{array}{l}-0.106 * * \\
(0.0411)\end{array}$ & $\begin{array}{c}-0.104^{* * *} \\
(0.0366)\end{array}$ & $\begin{array}{l}-0.00213 \\
(0.00982)\end{array}$ \\
\hline
\end{tabular}

Notes: Faculty-level data recording salary, courses taught and number of students for academic years 2002-03 to 2014-15 for the University of Michigan. Each cell-standard error indicates the coefficient on salary (measured in 000s) for a regression with the indicated teaching measure (column headings); regressions include year fixed effects. 